University at Buffalo School of Law

Digital Commons @ University at Buffalo School of Law

5-1-2019

\title{
The Legislature at War: Bandits, Runaways and the Emergence of a Virginia Doctrine of Separation of Powers
}

\author{
Matthew J. Steilen \\ University at Buffalo School of Law
}

Follow this and additional works at: https://digitalcommons.law.buffalo.edu/journal_articles

Part of the Constitutional Law Commons, and the State and Local Government Law Commons

\section{Recommended Citation}

Matthew J. Steilen, The Legislature at War: Bandits, Runaways and the Emergence of a Virginia Doctrine of Separation of Powers, 37 Law \& Hist. Rev. 493 (2019).

Available at: https://digitalcommons.law.buffalo.edu/journal_articles/953

\section{C) ${ }_{\text {COPYRIGHT }}^{\text {N }}$}

This Article is brought to you for free and open access by the Faculty Scholarship at Digital Commons @ University at Buffalo School of Law. It has been accepted for inclusion in Journal Articles by an authorized administrator of Digital Commons @ University at Buffalo School of Law. For more information, please contact lawscholar@buffalo.edu. 


\section{The Legislature at War: Bandits, Runaways and the Emergence of a Virginia Doctrine of Separation of Powers}

\section{MATTHEW STEILEN}

This is the story of a banditti that formed in the Virginia Southside during the early years of the American Revolution. We know little about it. What we do know comes down to us in fragments of patriot writing, not all of which are entirely trustworthy. Our banditti was led by Josiah Philips, a "laborer," writes Thomas Jefferson, "of daring \& ferocious disposition." He claimed to hold a military commission from Lord Dunmore, Virginia's royal governor, to recruit men into the king's service. In reality, says Jefferson, he was a brigand. He hid in the swamps during the day, and at night he emerged, "committing murders, burning houses, wasting farms, and perpetrating other enormities." One member of the gang, an escaped slave named Will, was thought particularly fearsome; a local militiaman tells us he struck "terror into the inhabitants of Norfolk and Princess Anne" counties. ${ }^{1}$

1. Jefferson to Louis Girardin, March 12, 1815, in The Papers of Thomas Jefferson, Retirement Series, vol. 8, 1 October 1814 to 31 August 1815, ed. J. Jefferson Looney

Matthew Steilen is a professor of law at the University at Buffalo School of Law $<$ mjsteile@buffalo.edu>. He thanks Christine Bartholomew, Chris Bates, Rebecca Brannon, Christa Dierksheide, Fred Konefsky, Jessica Lowe, Jonathan Manes, Laura McCoy, Andrew Jackson O’Shaughnessy, Peter Onuf, Xavier Salomon, Jack Schlegel, David Schwartz, Mitra Sharafi, and Justin Simard, as well as Editor Gautham Rao and three anonymous referees for Law and History Review, for help with the project or the manuscript. The Robert H. Smith International Center for Jefferson Studies, the Thomas Jefferson Library, and the special collections staff at the Library of Virginia, the Virginia Historical Society, and the John D. Rockefeller Jr. Library in Colonial Williamsburg kindly provided access to materials and other resources. The Smith Center and the University at Buffalo provided financial support. 
Even though we know little about this banditti, how patriot leaders wrote about it tells us much. The men of the gang met different fates: Philips was ordered to surrender by the state legislature in an "act of attainder"-more on this in a bit - and then caught, tried before a jury, and hanged. Will was shot for a bounty. Other slaves in the banditti were tried and hanged, their bodies left to decompose "in a conspicuous place." A jury sentenced one Jesse Phillpot to die by hanging, but, somehow, he died peacefully 4 years later at home. As Wayne Lee noted in his study of militia in revolutionary North Carolina, "Collective violence, even in the context of war, responded to social norms of legitimacy." What norms shaped the patriot response to the Philips banditti? How did patriots conceptualize the threat it posed, and how can we relate their views to their treatment of the gang? ${ }^{2}$

Did law shape the response of Virginia's leaders? Did the violence patriots used against Philips and his gang respond to legal norms, legal principles, legal understandings? The literature points in different directions. We know that some commanders in the continental army placed great emphasis on observing modern, refined, humane laws of war. These laws restricted armed conflict to "belligerents" and aimed to prevent violence from spilling over to the great injury of everyone else. Americans' observance of the laws of war distinguished them from the British (so they thought), who punished prisoners, plundered American farms, and even killed soldiers who did not resist. From today's perspective, the patriots' observance of the laws of war appears imperfect, and the conflict violent and disruptive, but the prevalence of law in the writings of patriot commanders is nonetheless apparent. ${ }^{3}$ Their concern was sibling to a broader

(Princeton, NJ: Princeton University Press, 2011), 334-38 (“daring \& ferocious," "committing murders"); Journal of the House of Delegates of the Commonwealth of Virginia; Begun [...] on Monday, the Fourth Day of May, in the Year of our Lord One Thousand Seven Hundred and Seventy-Eight (Richmond, 1827), 39 ("terror").

2. Norfolk County Order Book, August 3, 1778 and August 5, 1778, microfilm, County Court Order Books, Library of Virginia ("in a conspicuous place"); Virginia Gazette (Dixon and Nicholson), March 26, 1779, 2 (Phillpot's conviction); Virginia Antiquary, vol. 1, Princess Anne County Loose Papers, 1700-1789, ed. John Harvie Creecy (Richmond, VA: Dietz Press, 1954), 119 (Phillpot's death); Journal of the House of Delegates [May 1778], 39, 55 (Will's bounty); An act to attaint Josiah Philips, in The Statutes at Large; Being a Collection of All the Laws of Virginia [...], vol. 9 ed. William Waller Hening, (Richmond, 1821), 463-64; and Wayne E. Lee, Crowds and Soldiers in Revolutionary North Carolina: The Culture of Violence in Riot and War (Gainesville, FL: University of Florida Press, 2001), 138.

3. Holger Hoock, Scars of Independence: America's Violent Birth (New York: Crown, 2017), 17-20, 92-101, 250-68; and John Fabian Witt, Lincoln's Code, The Laws of War in American History (New York: Free Press, 2012), ch. 1. 
effort by American elites to obtain international recognition by conducting government according to a set of conventional legal forms. ${ }^{4}$ Another body of scholarly writing, however, treats law as too ethereal and indeterminate to properly explain patriot behavior, which aimed in fact at status, land, and power. Blackstone could have skipped his coverage of the law of nations, writes Eliga Gould, and "just as easily have written that the law was whatever Europe's rulers said it was." 5 The separation of powers, popular sovereignty - these were ideological ruses used to recruit common men into the service of the elite, whose only true interest, according to another writer, was endless land-jobbing. ${ }^{6}$ As still other studies have suggested, the "new men" who succeed in pushing their way into the corridors of power behaved much the same, employing their states' legislatures to confiscate the lands of loyalist neighbors, nearly all of whom were innocent of any real malum in se. American loyalists were stripped of their civil rights and property under cover of law. Perhaps, then, we should conclude that law was merely a tool used to advance other, more basal human interests. ${ }^{7}$

The problem becomes acute when we turn to men such as Josiah Philips and Will. Why was Philips's group a "banditti," a term typically used for robber gangs?" Why not a loyalist "militia," its members protected by the laws of war? ${ }^{9}$ Indeed, why not a revolutionary "committee"? ${ }^{10}$

4. Daniel J. Hulsebosch, "The Revolutionary Portfolio," Suffolk University Law Review 47 (2014): 764-70.

5. Eliga H. Gould, Among the Powers of the Earth: The American Revolution and the Making of a New World Empire (Cambridge, MA: Harvard University Press, 2012), 5.

6. Alan Taylor, American Revolutions: A Continental History, 1750-1804 (New York: Norton, 2016), ch. 10.

7. Ruma Chopra, Unnatural Rebellion: Loyalists in New York City during the Revolution (Charlottesville, VA: University of Virginia Press, 2011), 160.

8. Harry M. Ward, Between the Lines: Banditti of the American Revolution (Westport, CT: Praeger, 2002), ix-xi.

9. Loyalist militias were not unknown in Virginia. Jacob Ellegood, "a prominent man of an old, aristocratic Princess Anne family," earned a captain's commission from Dunmore "with authority to enlist one-hundred men." John Alonza George, "Virginia Loyalists, 1775-1783," Richmond College Historical Papers 1 (1916): 193. Ellegood was captured, paroled, and later sent over to the British in a prisoner exchange. H. J. Eckenrode, The Revolution in Virginia (Boston: Houghton Mifflin, 1916), 130, 143. For an account of how patriots handled loyalist militias and commanders in South Carolina, where the gentry was politically divided, see Rebecca Brannon, From Revolution to Reunion: The Reintegration of the South Carolina Loyalists (Columbia, SC: University of South Carolina Press, 2016), 52, 55, 59, 83.

10. "Committee" could be made to overlap with "banditti," at least for polemical purposes: "[I]t is the prevailing rage of the present times for people of all ranks, orders, and professions, to form Associations, and erect themselves into what they call Congresses and Committees of various denominations ... [and] in obedience to the orders of such Congresses and Committees, much private property has been destroyed, the most daring 
Maybe Jefferson found it impossible to believe that a laborer like Philips was motivated by genuine, independent political attachments, rather than an interest in plunder. Later, when a patriot militia plundered loyalists in the southwest part of the state, Governor Jefferson wrote to its gentleman commander that there would likely be no legal consequences, though he refused to ratify the conduct. The operative distinction between the two cases seems to be class. ${ }^{11}$ Race cleaved the Virginia revolutionary movement as well. Shouldn't we explain Will's fate by the fear of slave violence that was pervasive among Virginia planters? In the Carolinas, as Alan Taylor describes, "[p]atriots made special efforts to capture and execute black bandits." 12

This article makes a place for law in the story of the Philips banditti. Bandits were outlaws, men who habitually failed to heed the law, in a revolutionary society whose fragility made the exchange of allegiance for protection perhaps the most important element of membership. In mid-1775, as Virginia's planters tried to rouse the state to resist its royal governor, Philips led a mob against their efforts, sowing discontent among classes of men from whom the planters expected (and needed) deference. In 1777 and 1778, he organized some of these men into an armed gang, now accompanied by runaway slaves, and challenged the gentry who led government in the Southside. When reports emerged that his gang had murdered a militia captain, the Virginia General Assembly passed a bill accusing Philips of treason and ordering him to come in for trial or be summarily convicted. This was the act of attainder. ${ }^{13}$

piracies and robberies have been perpetrated in the face of open day, and death and destruction denounced against all who dare oppose their lawless banditti...." "For Mr. Rivington's New-York Gazetteer," April 6, 1775, in American Archives, Fourth Series [...], vol. 2, ed. Peter Force (Washington, DC: 1837), 284-85.

11. Jefferson to Arthur Campbell, August 9, 1780, in The Papers of Thomas Jefferson, vol. 3, 18 June 1779 to 30 September 1780, ed. Julian P. Boyd (Princeton, NJ: Princeton University Press, 1951), 534-35; Woody Holton, Forced Founders: Indians, Debtors, Slaves and the Making of the American Revolution in Virginia (Chapel Hill: University of North Carolina Press, 1999), ch. 6; and Michael A. McDonnell, The Politics of War: Race, Class, and Conflict in Revolutionary Virginia (Chapel Hill: University of North Carolina Press, 2010), ch. 4.

12. Philip J. Schwarz, Twice Condemned: Slaves and the Criminal Laws of Virginia, 1705-1865 (Baton Rouge: Louisiana State University Press, 1988), ch. 6; Alan Taylor, The Internal Enemy: Slavery and War in Virginia, 1772-1832 (New York: Norton, 2013), ch. 1-3; and Taylor, American Revolutions, 247 ("black bandits").

13. Ward, Between the Lines, ch. 10; Adele Hast, Loyalism in Revolutionary Virginia: The Norfolk Area and the Eastern Shore (Ann Arbor, MI: UMI Research Press, 1979), 74-85; and Eckenrode, Revolution in Virginia, 191-92. 
To make a place for law in this story is not to deny that race and class exerted a profound effect on those involved. Indeed, as we will see, race, class, and law intersected in the case in insidious ways. But a perception that the General Assembly had acted rashly or arbitrarily in condemning Philips arose later. Men's memories of the case differed from their experiences of it, which, for those leading the revolutionary government, are best described by what Paul Halliday has called "legal plurality."14 Legal plurality is an experience of a world as being populated by overlapping, competing legal jurisdictions. It was an experience familiar to British subjects in the crown's North American Empire. The act of attainder that the Virginia General Assembly passed against Josiah Philips was an expression of one such jurisdiction: the jurisdiction of the legislature to do justice when ordinary forms of law were ineffective, by ordering a dangerous fugitive to come in for trial or stand convicted. Jefferson, who drafted the bill, had studied this jurisdiction in considerable depth. Class and race played a central role in his thinking, as they did in the thinking of other Virginia elites, here as triggers of an extraordinary power. Class and race worked to foreground the gang's violence in his mind ("committing murders, burning houses, wasting farms"), and to frame it as a challenge to the very existence of civil government in the Southside. ${ }^{15}$ As Jefferson knew, these were the dangers for which legislative legal proceedings had long been invoked. It is therefore wrong to suggest, as one distinguished historian has, that Jefferson "could never quite reconcile" himself to the possibility that "anyone - high official or not - could be tried by an extraordinary court outside of the regular rules of law." Some men could. ${ }^{16}$

This article's second aim is to explore how this experience of the Philips case was displaced by a very different memory. It happened that there was little need for the General Assembly to attaint Philips: before the attainder could be publicized, he was captured by the Virginia militia, and subsequently tried and convicted of stealing twine and some felt hats. Ordinary law proved sufficient to punish a man perhaps less "daring \&

14. Paul Halliday, "Law's Histories: Pluralisms, Pluralities, Diversity," in Legal Pluralism and Empires, 1500-1850, ed. Lauren Benton and Richard Ross (New York: New York University Press, 2013), 268-73.

15. On the use of race in the patriot press during the Revolution, see Robert G. Parkinson, The Common Cause: Creating Race and Nation in the American Revolution (Chapel Hill: University of North Carolina Press, 2016), ch. 3. On the ways in which racial perceptions worked to divide white and black Virginians, see Philip J. Schwarz, Slave Laws in Virginia (Athens, GA: University of Georgia Press), 30-31.

16. Gordon S. Wood, Creation of the American Republic, 1776-1787 (Chapel Hill: University of North Carolina Press, 1998), 143. 
ferocious" than advertised. This cast the act of attainder as an interference in the ordinary judicial process. From the perspective of a group of professional, learned lawyers in Virginia, legislative interference in the courts was intolerable. In the late 1770 s and 1780 s, these men spearheaded an effort to reform the state's courts, extending the methods of professional lawyers in the central General Court throughout Virginia's historically devolved judicial system. ${ }^{17}$ Jefferson himself championed these reforms. Although he never ceased defending legislative jurisdiction in the Philips case, others looking back on the case could not help but see things differently. If gentlemen sitting in the General Assembly could arbitrarily interfere with judicial proceedings in (what turned out to be) a serious but ordinary case, no case would be immune, and such a practice would vitiate the benefits of professional, learned law.

With the legislature's assertion of legal jurisdiction impugned, the way was opened to characterize acts of attainder as an abuse of lawmaking power, rather than an extraordinary legal power. This is precisely how St. George Tucker describes the Josiah Philips case in his edition of Blackstone's Commentaries, prepared in the early 1790s. ${ }^{18}$ For Tucker, the significance of the Philips case lay in demonstrating the importance of a clear, judicially enforceable boundary between the legislature and courts of law. This would have profound effects on republican government in Virginia. By refusing to execute backward-looking legislative judgments that deprived individuals of their lives or property, courts would displace the assembly, substituting their learned exposition of the constitution for a paternal decision of the state's great men that the ordinary course of justice had to give way to preserve the security of their households. ${ }^{19}$ What Robert Cover has called the "jurispathic" (law-killing) power of courts was thus turned inward, toward government, and used to confine the legal jurisdiction of a superior body, the legislature. ${ }^{20}$ It is only here, in

17. A. G. Roeber, Faithful Magistrates and Republican Lawyers: Creators of Virginia Legal Culture, 1680-1810 (Chapel Hill: University of North Carolina Press, 1981); F. Thornton Miller, Juries and Judges Versus the Law: Virginia's Provincial Legal Perspective, 1783-1828 (Charlottesville, VA: University of Virginia Press, 1994), ch. 1; William E. Nelson, The Common Law in Colonial America, vol. 3, The Chesapeake and New England, 1660-1750 (New York: Oxford University Press, 2016), 46-52.

18. St. George Tucker, Blackstone's Commentaries: With Notes of Reference [...], vol. 1 (Philadelphia: 1803), 292-93.

19. On the republican legislature and the household of the Virginia patriarch, see Matthew Crow, Thomas Jefferson, Legal History, and the Art of Recollection (Cambridge: Cambridge University Press, 2017), 88-89, 105; and Peter S. Onuf, "Making Sense of Jefferson," in The Mind of Thomas Jefferson (Charlottesville, VA: University of Virginia Press, 2007), 33.

20. Robert Cover, "Foreword: Nomos and Narrative," Harvard Law Review 97 (1983): $40-44$. 
the 1790s, that we see the real beginnings of a Virginia doctrine of separation of powers. The famous provisions of the 1776 Virginia Constitution separating the departments and their powers must be read with an understanding that the assembly could adjudicate some cases itself, and influential histories that treat the 1776 provisions in isolation from this practice need revision. ${ }^{21}$ Likewise, Jefferson's oft-repeated complaint, written in 1781 or thereabouts, that the General Assembly had "decided rights which should have been left to judiciary controversy," cannot be read to refer to legislative adjudication per se, which Jefferson defended in the Philips case, but only to its improper use. ${ }^{22}$

To get back behind all of this, to understand how elites first experienced the patriot response to the Philips banditti, the story needs to begin at some remove, to travel some distance into English legal history. This is necessary to get the legal perspective right, which, at least in Jefferson's case, was formed by a sustained encounter with a body of texts largely unfamiliar to historians of the eighteenth century. The article then turns to the opening of the Revolution in Virginia, focusing on the gentry's experience of the breakdown of civil government in the Southside and the formation of the Philips banditti. I consider in detail the legal sources that Jefferson drew on to decide on the proper legal response to Philips. The last two sections explore how professionalization and court reform led Virginians to recast the legislature's involvement in very different terms.

\section{Antecedents: Parliamentary Attainder in England and Empire}

Legal proceedings in the English Parliament leave a long trail in books. Under Edward I there developed a practice of curing injustice by hearing private petitions in Parliament. ${ }^{23}$ Bills, which in this period were

21. M. J. C. Vile, Constitutionalism and the Separation of Powers (Oxford: Clarendon Press, 1965), 119; and Willi Paul Adams, The First American Constitutions: Republican Ideology and the Making of the State Constitutions in the Revolutionary Era (Lanham, MD: Rowman \& Littlefield, 2001), 265. The relevant provisions of the 1776 Virginia Constitution are section V of the Declaration of Rights, which states that "the legislative and executive powers of the state should be separate and distinct from the judicative," and the Form of Government, which requires that "[t]he legislative, executive, and judiciary department, shall be separate and distinct, so that neither exercise the powers properly belonging to the other."

22. Thomas Jefferson, Notes on the State of Virginia, ed. William Peden (Chapel Hill: University of North Carolina Press, 1982), 120.

23. Gwilym Dodd, Justice and Grace: Private Petitioning and the English Parliament in the Late Middle Ages (Oxford: Oxford University Press, 2007), 27-28; and G. O. Sayles, The King's Parliament of England (New York: Norton, 1974), 77. 
imperfectly distinguished from petitions, could also be presented in Parliament, where they, too, functioned to cure residual injustice, so that "if redress could not be obtained by a writ, the injured party could claim the right to go to the king or to the king's representatives and ask for redress in their presence." ${ }^{24}$ Complaining by petition or bill was less formal than proceeding by writ original in the common law courts. Plaintiffs had merely to show, in piteous language, that they had suffered some trespass or loss that the law could not remedy. Not uncommonly, the wrongdoer was the king's own officer or commissioner. The prayer worked to align the petitioner with the King, who had sworn to do justice and keep the peace.

Turning to high politics (another, sometimes indistinguishable, aspect of Parliament's business), there were similar ideas at work. Country lords opposed to Richard II lodged an "appeal" in Parliament against his courtiers for traitorously corrupting him. What, precisely, an "appeal of treason" was, we are not entirely certain (they may not have been, either); but possibly it was meant to invoke a much older, non-common law proceeding, the "appeal of felony," a kind of private criminal suit heard in the ancient local courts. Most of the courtiers fled and did not appear in Parliament to defend themselves, but the "lords appellant" insisted that the appeal proceed to judgment nonetheless. Common-law courts generally did not condemn the absent, but under the less restrictive "laws and course of Parliament," the lords said, judgment could be entered against the absent for notorious offenses. ${ }^{25}$ "Notorious" offenses were particularly heinous and publicly known, and the principle that they could be prosecuted in absentia was familiar to students of military and canon law. By asserting it in Parliament, the lords staked out a summary jurisdiction over state crimes that could not be punished in ordinary courts. ${ }^{26}$

24. G. O. Sayles, ed., Select Cases in the Court of King's Bench under Edward II, vol. IV, Selden Society volume 74 (London: Selden Society, 1955), lxviii-lxix; and Alan Harding, "Plaints and Bills in the History of English Law, mainly in the period 1250-1350," in Legal History Studies 1972, ed. Dafydd Jenkins (Cardiff: University of Wales Press, 1972), 80. Here Harding is describing bills before the king's justices in eyre, but he argues that bills played the same role in Parliament.

25. Chris Given-Wilson, ed., The Parliament Rolls of Medieval England, 1275-1594, vol. 7, Richard II: 1385-1397 (London: Boydell, 2005), 100-101.

26. John Collins, Martial Law and English Laws, c.1500-c.1700 (Cambridge: Cambridge University Press, 2016), 18; Kenneth Pennington, "The Jurisprudence of Procedure," in The History of Courts and Procedure in Medieval Canon Law, ed. Kenneth Pennington and Wilfrid Hartmann (Washington, DC: Catholic University Press, 2016); John M. Collins, "Hidden in Plain Sight: Martial Law and the Making of the High Courts of Justice, 1642-1660," Journal of British Studies 53 (2014): 870; and T. F. T. Plucknett, "The Origin of Impeachment," Transactions of the Royal Historical Society, Fourth Series 24 (1942): 57-61. 
The "bill of attainder" was a natural successor to these constitutional traditions. It expressed the fifteenth century view that in Parliament, the king's power was at its greatest, assembled with all his lords and the common of the realm, and that in such an august assembly he might do justice where other courts, and even his council, could not. Over time, writers theorized this by describing the "King's high court of Parliament." 27 A high court could correct failures of justice caused by the limits of inferior courts. And a high court could concern itself with high politics: matters involving over-mighty or ungovernable subjects, in which injustice might be too costly to the realm to leave unaddressed. Proceeding by bill (or, similarly, by "common petition") allowed for Parliament to perform these functions: reciting what was known; calling the defendant (if need be); and resolving the matter by judgment, ordinance, or act. ${ }^{28}$ In this way, parliamentary attainder took its place beside military courts, the King's Council, justices of the peace and, somewhat later, the Star Chamber, as a summary legal jurisdiction employed to manage issues of security, domestic peace, and police. $^{29}$

The idea that Parliament was a "high court" proved to have remarkable staying power, or, at least, to reappear when it most seemed useful and right. Legal and political texts describe Parliament as a "high court" well past the English Reformation, when most historians would regard Parliament as a proper lawmaking body with a permanent place in the English constitution. ${ }^{30}$ Seventy years after the Reformation, common lawyers invoked the idea of Parliament as a high court to check abusive monopolies granted by King James. If exploiting royal monopolies for private gain was, as they believed, illegal, then to adjudicate the grievance in Parliament it became essential to show that "parliament was not just a legislature; it was also a court and a council." 31 Thus we see the growth of a number of now-familiar quasi-judicial parliamentary powers, including powers to summon men and gather papers for investigations, to imprison for contempt, and to impeach patentees and even ministers for abusing

27. S. B. Chrimes, English Constitutional Ideas in the Fifteenth Century (Cambridge: Cambridge University Press, 1936), 70-85.

28. Matthew Steilen, "Bills of Attainder," Houston Law Review 53 (2016): 788.

29. Collins, Martial Law and English Laws (military courts), 29-52; John H. Langbein, Renee Lettow Lerner, and Bruce P. Smith, History of the Common Law (New York: Aspen Publishers, 2009), 230-36 (justices of the peace), 563-75 (Star Chamber); and James Fosdick Baldwin, The King's Council in England During the Middle Ages (Oxford: Clarendon Press, 1913), ch. 11-12.

30. Thomas Smith, De Republica Anglorum (1583), Book II, ch. 1 and 6.

31. Alan Cromartie, The Constitutionalist Revolution: An Essay on the History of England, 1450-1642 (Cambridge: Cambridge University Press, 2006), 191. 
their powers. ${ }^{32}$ Bills of attainder also found use. Although bills in Parliament were by then used to pass legislation, the bill power could also be used for adjudication, and members acknowledged the ambiguity. ${ }^{33}$ Less appreciated was the exact relationship that these parliamentary proceedings bore to the common law. Which body of law was superior? Parliamentarians sought to limit the king's prerogative where it trenched on common law rights, but then refused such limits in derogation of the House of Commons' power to interrogate and imprison. This inconsistency was not lost on the victims, who pointed out the tension between the House of Commons' assertion that its power to arrest for contempt was unreviewable on a writ of habeas corpus, and Paragraph V of the Petition of Right, which complained of just this practice by the king. ${ }^{34}$ Bills of attainder triggered a similar difficulty, a point that Coke clearly struggles with in his discussion of parliamentary attainder in the Institutes. ${ }^{35}$

Violent civil conflict was thus governed by a host of overlapping legal regimes, and the management of conflicts among these regimes was part of a collective project of "constitution-making." ${ }^{36}$ In England, this project resulted in a decline and then abandonment of attainder for treason over the 150 years between the Civil War and the end of the eighteenth century. Impeachments, too, eventually ceased. The causes of this development are complex, but two events stand out. First, a cultural embrace of the common law in the seventeenth century made the disastrous attainders of Thomas Wentworth, Earl of Strafford, and Sir John Fenwick appear as exercises of "absolute" or "mere" legislative power, rather than as summary legal power. Their executions seemed to contemporaries best explained by politics in the council and the House of

32. Edward Coke, The Fourth Part of the Institutes (London, 1644), 37 (attainder); J. W. Gough, Fundamental Law in English Constitutional History (Oxford: Clarendon Press, 1955), 43 (attainder); Stephen D. White, Sir Edward Coke and "The Grievances of the Commonwealth" (Chapel Hill: University of North Carolina Press, 1979) (committee investigations); and Colin G. C. Tite, Impeachment and Parliamentary Judicature in Early Stuart England (London: Athlone Press, 1974) (impeachment).

33. For example, the speech of Lord Digby in 1641 during the Strafford attainder: "[T]here is in Parliament a double Power of Life and Death by Bill, a Judicial Power, and a Legislative." John Rushworth, The Tryal of Thomas, Earl of Strafford (London: 1680), 53. Members also debated the use of bills to adjudicate the scope of the sovereign's prerogative. Cromartie, Constitutionalist Revolution, 191-94.

34. Josh Chafetz, Democracy's Privileged Few: Legislative Privilege and Democratic Norms in British and American Constitutions (New Haven, CT: Yale University Press, 2007), 32-37; and Paul D. Halliday, Habeas Corpus: From England to Empire (Cambridge, MA: Harvard University Press, 2010), 215-19.

35. Coke, Fourth Part of the Institutes, 37; and Steilen, "Bills of Attainder," 820-22.

36. Daniel Hulsebosch, "Constitution-Making in the Shadow of Empire," American Journal of Legal History 56 (2016): 85-86. 
Commons. ${ }^{37}$ Non-capital prosecutions by bill did persist, but these were increasingly distinguished by different names, such as the "bill of pains and penalties." 38 An act of attainder was last used to condemn someone to death in 1746, following the Jacobite rising, and then only against those who had fled or were in open rebellion. ${ }^{39}$ Second, in the early eighteenth century, King's Bench found success in using prerogative writs such as mandamus, certiorari, and habeas corpus to police and manage the conflicts among different English jurisdictions, including the special commissions and similar bodies that were growing into agencies of a modern administrative state. The court thereby put itself at the center of English government. ${ }^{40}$ In contrast, the supervisory and remedial authority of the Parliament crystalized as a power to constitute courts and delegate legal power, which it used to confer significant discretion on the council in matters of security and police. Parliament might make new jurisdictions, or prevent bail by suspending the writ of habeas corpus, but only the House of Lords could directly exercise legal power. ${ }^{41}$

Beyond the realm of England, however, in the provinces of the North American Empire, the story looks somewhat different. It is well known that early American assemblies possessed powers of judicature. These powers were not thought anachronistic or left to lie fallow; lower houses, in particular, regarded judicature as fortifying the colonial assembly's claims to the privileges and status of the great English Parliament. ${ }^{42}$ In Virginia, the General Assembly both exercised original jurisdiction in serious criminal matters and acted as a court of last resort. ${ }^{43}$ Its upper house,

37. Steilen, "Bills of Attainder," 796-825.

38. Other non-capital punitive bill proceedings included exile and contempt of parliamentary process. William Richard Stacy, "The Bill of Attainder in English History" (PhD diss., University of Wisconsin-Madison, 1986), ch. 12-13.

39. Stacy, "Bill of Attainder in English History," 588, 590. Archibald Cameron, who was condemned in the 1746 act of attainder, was caught and executed in 1753. Fenwick, however, was likely the last person condemned by an act of attainder in lieu of a common law trial. Ibid., 589.

40. Halliday, Habeas Corpus, 137-46; and Louis L. Jaffe and Edith G. Henderson, "Judicial Review and the Rule of Law: Historical Origins," Law Quarterly Review 72 (1956): 355-64.

41. Paul D. Halliday and G. Edward White, "The Suspension Clause: English Text, Imperial Contexts, and American Implications," Virginia Law Review 94 (2008): 616-28.

42. Mary Patterson Clarke, Parliamentary Privilege in the American Colonies (New Haven, CT: Yale University Press, 1943), 54.

43. Warren M. Billings, A Little Parliament: The Virginia General Assembly in the Seventeenth Century (Richmond: Library of Virginia, 2004), 149, 171; and Scott Douglas Gerber, A Distinct Judicial Power: The Origins of an Independent Judiciary, 1606-1787 (Oxford: Oxford University Press, 2011), 50. 
the Council of State, was also the colony's highest ordinary court, and councilors amassed perhaps the colony's greatest collection of law books at Williamsburg. ${ }^{44}$ In conducting itself judicially, the council employed bill proceeding rather than the more formal proceeding by original writ, and pleading was handled liberally. ${ }^{45}$ Records suggest that this was by choice rather than ignorance, as the language implies some familiarity with the "laws and course of Parliament." Thus, for example, William Tiballs and Henry Gee were brought before the council for being "notorious actors, aydors and assistors in the late rebellion," and banished without a trial. ${ }^{46}$ Occasionally, the full General Assembly (Council and House of Burgesses together) condemned traitors by enactment. For leading a rebellion of planters against Governor William Berkeley, Nathanial Bacon and his "notorious confederates" were "adjudged to be convicted and attainted of high treason" "by vertue of this act" - a mixture of judicial and legislative terminology that could have been cut straight from the Parliament rolls of medieval England. ${ }^{47}$

These practices change significantly in the eighteenth century. Lower houses and bicameral assemblies lost much of their jurisdiction, which was delegated to courts of common pleas, quarter sessions, and assizes. ${ }^{48}$ In Virginia, the British Privy Council replaced the colonial General Assembly as the court of last resort, although the legislature's upper house, the Council of State, did remain the highest ordinary court. ${ }^{49}$

44. Brent Tarter, "The Library of the Council of Colonial Virginia," in "Esteemed Bookes of Lawe" and the Legal Culture of Early Virginia, ed. Warren M. Billings and Brent Tarter (Charlottesville, VA: University of Virginia Press, 2017), 41.

45. Billings, A Little Parliament, 165-66; and William E. Nelson, The Common Law in Colonial America, vol. 1, The Chesapeake and New England, 1607-1660 (New York: Oxford University Press, 2008), 37. Liberal pleading should not be taken to imply arbitrary decision making; as Nelson himself observes, the General Court was outspoken in its embrace of "rule of law," partly in an effort to attract settlers to the colony. Nelson, Common Law, 1:26-28.

46. William Waller Hening, ed., The Statutes at Large; Being a Collection of All the Laws of Virginia [...], vol. 2 (New York, 1823), 555 (emphasis mine).

47. Ibid., 2:375.

48. Alison G. Olson, "Eighteenth Century Colonial Legislatures and their Constituents," Journal of American History 79 (1992): 566; James A. Henretta, "Magistrates, Common Law Lawyers, Legislators: The Three Legal Systems of British North America," in Cambridge History of Law in America, vol. 1, ed. Michael Grossberg and Christopher Tomlins (Cambridge: Cambridge University Press, 2008), 569-76; and Jack P. Greene, The Quest for Power: The Lower Houses of Assembly in the Southern Royal Colonies, 1689-1776 (Chapel Hill, NC: University of North Carolina Press, 1963), 332-33.

49. Leonard Woods Labaree, ed. Royal Instructions to the British Governors, 1660-1776, vol. 1 (New York: American Historical Association, 1935), 320-21; and Roeber, Faithful Magistrates, 44, 51. 
Where legislative legal powers grew, they tended to assume a different form. Some colonial assemblies exercised legal power by superintending courts of law, overturning their judgments, and "restoring" litigants thought to have suffered injustice. ${ }^{50}$ Perhaps the most important legal legislative power in the eighteenth century was the power of the purse. The core of that power, claimed by the Virginia House of Burgesses, was initiating revenue bills. But control over the purse could entail much else besides: evaluating and paying claims against the government of the colony, indemnifying officers for exceeding the bounds of their power, and demanding an accounting of expenditures from government. Assemblies also asserted powers to appropriate tax monies and to audit government accounts, and (in most colonies, although not in Virginia) occasionally defunded the salaries of unpopular officers, including royal governors. ${ }^{51}$ In these ways, attending to the purse involved "legislative adjudication," as Christine Desan has aptly described it. ${ }^{52}$

A second development important in Virginia was the rise of the county justice of the peace, around whom an oppositional, "country" mentality crystalized in the first decades of the eighteenth century. This became perhaps the colony's most important judgeship. Elite planters used the office to solidify local control over the production and sale of tobacco, the accompanying system of credit and debt, religious conformance, parish management, family, and morality. Most gentleman justices were planters and not practicing lawyers, although a significant number attended one of the English Inns of Court. ${ }^{53}$ They coveted law books (there was one in every planter's home, even if there was not a Bible), but it was country

50. John Phillip Reid, Legislating the Courts (Dekalb, IL: Northern Illinois University Press, 2009): 7-11; and Phillip Hamburger, Law and Judicial Duty (Cambridge, MA: Harvard University Press, 2008), 525-32.

51. Greene, The Quest for Power, 51; Evarts Boutell Greene, The Provincial Governor in the English Colonies of North America (New York: Russell and Russell, 1966), 59-60, 18088; Edmund S. Morgan, Inventing the People: The Rise of Popular Sovereignty in England and America (New York: Norton, 1988), 140; and Lucille Griffith, The Virginia House of Burgesses, 1750-1774 (Birmingham, AL: University of Alabama Press, 1970), 17.

52. Christine A. Desan, "The Constitutional Commitment to Legislative Adjudication in the Early American Tradition," Harvard Law Review 111 (1998): 1391-427. A recent treatment of the power of the purse describes how targeted appropriations, auditing, removal, sunset clauses, and appointment of treasurers gave colonial legislatures significant control over the conduct of government. Josh Chafetz, Congress's Constitution: Legislative Authority and the Separation of Powers (New Haven, CT: Yale University Press, 2017), 45-77, 92-93.

53. Nelson, Common Law, 3:33-37, 47-52; Roeber, Faithful Magistrates, 34-41, 71-72, 123, table 4; and Gwenda Morgan, The Hegemony of the Law: Richmond County, Virginia, 1692-1776 (New York: Garland Publishing, 1989), ch. 2. 
justice manuals that they prized most, rather than the professional lawyers' Coke on Littleton. A Virginian, George Webb, even wrote a manual for justices of the peace, The Office and Authority of a Justice of the Peace (1736), which circulated widely alongside several English manuals. Webb declared that his manual "avoided all references to Laws and Law-Books" beyond those strictly necessary, and that "a true Judgement" was formed by adapting "General Rules and Maxims" to a particular case. ${ }^{54}$ Common law writs and rules of pleading were employed in civil actions before the justices, empaneled as a "county court," but the boundary between their legal and equitable jurisdictions was sometimes unclear and "the ease of moving from law to equity guaranteed a kind of informality." In sum, concludes William Nelson, "Power was exercised by local elites, who often possessed some training in the law and who ruled as they thought best." 55

Together, these developments left the legislature's power to condemn by bill somewhat uncertain at the time of the imperial crisis. Lawyers were likely to have heard of attainder, but there was no clear, shared sense of how to fit this ancient jurisdiction alongside its local, provincial, and imperial competitors. ${ }^{56}$ As Daniel Hulsebosch, Lisa Ford, and others have shown, violent conflict, particularly on the frontier and at sea, required settlers, traders, indigenous peoples, and imperial administrators to manipulate the overlapping claims of customary law, admiralty, and the common law. In the Virginia Tidewater, too, imperial and local legal regimes could overlap to upset the expectations of the gentry and the people they kept as slaves. A justice of the peace faced with a runaway slave, alleged to have a committed an offense during a time of war, had first to settle on the law, a decision that could mean the difference between a

54. Rhys Isaac, The Transformation of Virginia: 1740-1790 (Chapel Hill: University of North Carolina Press, 1982), 92-93, 133; Warren M. Billings, "English Legal Literature as a Source of Law and Practice in Seventeenth Century Virginia," in Billings and Tarter, "Esteemed Bookes of Lawe", 19-21; Louis B. Wright, The First Gentlemen of Virginia (San Marino, CA: The Huntington Library, 1940), 123-33; Roeber, Faithful Magistrates, 56-59; George Webb, The Office and Authority of a Justice of the Peace (Williamsburg: 1736), ix; and Miller, Juries and Judges, 6.

55. Roeber, Faithful Magistrates, 44 ("ease of moving"); Nelson, Common Law, 3:43-45, 49-50; R. T. Barton, "Introduction," in John Randolph and Edward Barradall, Virginia Colonial Decisions, vol. 1, ed. R. T. Barton (Boston: Boston Book, 1909), 198-99. A study of the Norfolk County Court and the Norfolk Borough Hustings Court states that the courts "seemed to follow rules strictly, though perhaps not always to the detriment of litigants. They seemed comfortable with familiar rules and forms." E. Lee Shepard, "The Administration of Justice in Revolutionary Virginia: The Norfolk Courts, 1770-1790" (master's thesis, University of Virginia, 1974), 17.

56. Steilen, "Bills of Attainder," 772-73, 826-31. 
sentence of whipping, hard labor, exile, death, transfer to another court, or "release" to the patriarchal discipline of the master. ${ }^{57}$

Understanding how Virginians tried to answer these questions requires a sense of the cases in which the questions were presented. We are searching for how men thought about those cases, how they approached them, and how they conceived of the problems and the people involved. What did Virginia gentlemen see when they looked at Josiah Philips and his gang? To what body of law did their perceptions point?

\section{Discontent and the Opening of War in the Tidewater}

Josiah Philips was a laborer who lived in Lynnhaven Parish, in Princess Anne County, an area now part of Virginia Beach. In the late summer of 1775 he came to the attention of the volunteer militia companies then lingering in the heat at Williamsburg. George Gilmer, Thomas Jefferson's close friend and commander of a volunteer company from Albemarle County, recorded the observation in his diary, which he used to document the companies' activities and their officers' correspondence with the Third Virginia Convention, then in session. "It is certain," Gilmer wrote, "that one Phillips commands an Ignorant disorderly mob who are in direct opposition to our plan." 58 What "plan" he meant is not immediately clear. 59 Two days later, the clerk of the convention, John Tazewell, entered the

57. Daniel J. Hulsebosch, Constituting Empire: New York and the Transformation of Constitutionalism in the Atlantic World, 1664-1830 (Chapel Hill: University of North Carolina Press, 2005), 42-104; Lisa Ford, Settler Sovereignty, Jurisdiction and Indigenous People in America and Australia, 1788-1836 (Cambridge, MA: Harvard University Press, 2010), 3-24; Gould, Among the Powers of the Earth, ch. 1; and David Thomas Konig, "Virginia and the Imperial State: Law, Enlightenment, and 'The Crooked Cord of Discretion," in The British and their Laws in the Eighteenth Century, ed. David Lemmings (Suffolk: Woodbridge, 2005), 220. For an extension of these issues to the 1780 s and the framing of the federal Constitution, see Gregory Ablavsky, "The Savage Constitution," Duke Law Journal 63 (2014): 1009-18.

58. George Gilmer, Commonplace Book, August 1, 1775, p. 65, Mss 5: 5 G4231:1, Virginia Historical Society; and Robert L. Scribner, ed., Revolutionary Virginia, The Road to Independence, vol. 3, The Breaking Storm and the Third Convention, 1775 (Charlottesville, VA: University of Virginia Press, 1977), 385, 388 n.23.

59. Gilmer "was a leader of the activists" among the volunteer companies' officers, and it was he who proposed that the companies seize public moneys in the name of the convention. Courtlandt Canby, "The Commonplace Book of Doctor George Gilmer," Virginia Magazine of History and Biography 56 (1948): 383. By August 1, that plan had already come to naught, as the convention resolved that the "proceedings of the Volunteer Companies ... cannot be approved, and that they be requested to desist from carrying their resolution into action. [signed] A Copy John Tazewell Clerk of the Convention." Gilmer, Commonplace Book, 62. 
officers' minutes in the Convention Proceedings. Tazewell described Philips as opposed "the measures of this Country," that is, Virginia. But which ones? ${ }^{60}$

At the time, the Third Convention was occupied largely with military preparations. In late July it had provided for raising two regiments of regulars and 8,000 militiamen, to be paid for their service in paper notes. The law exempted men from militia duty if they owned four or more slaves, and gentlemen accepting an officer's commission drew pay more than ten times that of the enlisted, causing a resentment that Woody Holton has described as "emerging class consciousness." ${ }^{1}$ In early spring, the Second Virginia Convention had recommended that county committees "collect from their constituents, so much money, as will be sufficient," to purchase gunpowder, lead and flint, a levy to be apportioned "as the committee shall judge requisite." 62 This measure, too, caused discontent. Why shouldn't wealthy officers provide the muskets and powder? Alexander Miller thought it unfair, and announced the planter class "would take every half-bitt they had" to "mak[e] gentlemen of themselves." As a loyalist later explained, describing the hundreds who lined up to swear loyalty to the king after the British victory at Kemp's Landing, "poor people blame these men [i.e., patriots] for obliging them to take up arms." 63 To hear such views expressed in public, in open defiance of the convention and the county committees, caused Virginia's great men worry. Writing to Edmund Pendleton about such a case, John Richards could hardly believe it. "[O]ur cause is too good to be prejudiced by any person of his

60. Scribner, Revolutionary Virginia, 3:393.

61. An ordinance for raising and embodying a sufficient force, for the defense and protection of this colony, in Hening, Statutes at Large, 9:9-34; and Holton, Forced Founders, 168. The pay differential between officers and enlisted men was greater in the Southern colonies than in the North, whose armies at first aimed to embody Whig principles of equality. When George Washington assumed control of the New England Army (which became the Continental Army), eliminating pay equality was one of his chief goals. Jerrilyn Greene Marston, King and Congress: The Transfer of Political Legitimacy, 1774-1776 (Princeton, NJ: Princeton University Press, 1987), 150, 158-64.

62. The Proceedings of the Convention of Delegates [...] March, 1775 (Richmond: 1816), 6-7. The matter was felt urgent after Governor Dunmore emptied the Williamsburg magazine of powder in late April. See, for example, the Resolution of the Gloucester County Committee, April 25, 1775, in Force, American Archives Fourth Series, 2:387-88.

63. Virginia Gazette (Purdie), November 3, 1775 ("every half-bitt they had"); Neil Jamieson to Messrs. Glassford, Gordon, Monteath, and Co., November 17, 1775, in Revolutionary Virginia: The Road to Independence, vol. 4, The Committee of Safety and the Balance of Forces, ed. Robert L. Scribner and Brent Tarter (Charlottesville, VA: University of Virginia Press, 1978), 423. 
Insignificancy." The man had always been "very Industrious, Quiet \& saying little to any person." 64

The continental agreement to stop the importation of British goods was meeting increased resistance as well. In Virginia, implementation fell to the gentlemen of the revolutionary county committees, and Lingley tells us that the Norfolk County Committee was dutifully "industrious" in enforcing the rules. Yet the weight of the policy was unevenly borne. Banning imports hurt the county's merchants, who were unable to conduct much of their business. Some understandably expressed a desire for Virginia to remain neutral in the dispute or even for the colonies to acquiesce. ${ }^{65}$ Landless farmers, laborers, pilots, and mechanics also saw their incomes decline, and, lacking cash reserves, struggled to pay their rent. This was a significant population: the landless comprised over half the population in Princess Anne. Landlords (including George Washington and Richard Henry Lee) fixed rents at certain quantities of gold or silver coin, though their tenants could pay only in depreciating paper notes. ${ }^{66}$ In August, the provincial convention elevated non-importation to a full embargo, and by autumn, the British naval blockade of the Chesapeake made it difficult even to smuggle in necessities. Insurrection threatened in several counties for lack of salt. ${ }^{67}$ Perhaps we should imagine, then, Josiah Philips reciting these complaints at the head of an agitated crowd of laborers and merchants' employees in Williamsburg. Or, better yet, drifting into the Norfolk docks on a British tender, as Lord Dunmore's agents reportedly did, whispering to "the fishermen and all the lower class of people" that "those who advised them to take up arms" were in truth "their greatest enemies." 68 We cannot be certain, but stress was great, and many ordinary

64. John Richards to Edmund Pendleton, December 14, 1775, in "Virginia Legislative Papers (Continued)," Virginia Magazine of History and Biography 14 (1907): 391 (emphasis mine); McDonnell, Politics of War, 127. The culprit, Jonathan Dew or Daw, had been recruiting men to fight for the king by promising them "four new shirts \& a good set of clothes \& paid for their washing," in addition to pay and quarter. Deposition of Charles E. Woods, Virginia Magazine of History and Biography 14 (1907): 392.

65. Charles Ramsdell Lingley, The Transition in Virginia from Colony to Commonwealth (New York: Columbia University, 1910), 119; Shepard, "The Administration of Justice," 46-47; Hast, Loyalism in Revolutionary Virginia, 96-99; George, "Virginia Loyalists," 173, 184-89; and Eckenrode, Revolution in Virginia, 100.

66. Holton, Forced Founders, 176; Shepard, "The Administration of Justice," 87. According to Shepard, 55\% of people in Princess Anne were landless. More broadly, throughout the Southside, "people ... tended to be landless."

67. Ivor Noel Hume, 1775: Another Part of the Field (New York: Knopf, 1966), 281, 370-71; and Holton, Forced Founders, 173-74.

68. Northampton Committee of Safety to the Continental Congress, November 25, 1775, "Virginia Legislative Papers (Continued)," Virginia Magazine of History and Biography 14 (1907): 254. 
men publicly despaired about the direction of affairs. As William Axtead told his neighbors,

$[I] t$ was useless to contend any longer; for they would be dam'd if the King would ever give up Independency to America, that the present Dispute would never be settled unless by Mobbs, that the People of this Country would never be so well off as they had been, for they would never be able with the same Quantity of any of their Commodities to purchase so much Sugar as they formerly could, that the Poor People of this County would be sold to support the Gent; ... saying God damn the Guard [i.e., the militia] and ... the first Son of a Bitch that durst offer to take a Piece of Meat out of the House for the use of the Guard should have his back broke with an iron Pestle \&ca. ${ }^{69}$

Sometime later, George Mason would insist that "[t]here was never an idler or falser notion than that which the British ministry have imposed upon the nation, that this great Revolution has been the work of a faction, of a junto of ambitious men, against the sense of the people of America." Nothing, Mason insisted, "has been done without [their] approbation"although he quickly added praise for "the cordial manner in which they have cooperated," not sensing the tension. But even if Mason was blind to it, the British certainly saw a divergence between the interests of the great planters and the landless classes, and Lord Dunmore advised the ministry to exploit it. ${ }^{70}$ It would be natural, then, for Dunmore to have employed a man like Josiah Philips, who could convincingly describe how the costs of revolution had fallen unfairly on the poor. Dunmore felt comfortable using such men. He reputedly commissioned a Williamsburg stocking maker, Adam Allen, to be his agent in "secret service," and tasked him with stealing the colony's Great Seal from the patriot-controlled capitol. ${ }^{71}$ Philips, too, later claimed to have a commission from Dunmore to recruit, although there is no supporting evidence of it in public records. ${ }^{72}$

69. Virginia Antiquary, 1:103-4. For this, Axtead was brought before two Princess Anne justices of the peace and then released on bond for good behavior.

70. Mason to George Mercer, October 2, 1778, in The Life of George Mason, 1725-1792, vol. 1, ed. Kate Mason Rowland (New York: 1892), 299; Dunmore to Earl of Dartmouth, in The Writings of George Washington from the Original Manuscript Sources, 1745-1799, vol. 3, January, 1770-September, 1775, ed. John C. Fitzpatrick (Washington, DC: Government Printing Office, 1931), 249 n.94.

71. Hume, Another Part of the Field, 341-42.

72. I have not found evidence of an officer's commission in state papers; the list of men commissioned by Dunmore in 1775 and 1776 to be part of the Queen's Loyal Regiment does not include Philips. Public Record Office Class T1/580/113-114, microfilm, Virginia Colonial Records Project, Library of Virginia. Neither is there evidence of any payments to Philips in Dunmore's accounts that I have examined. PRO Class T1/580/128-129, Virginia Colonial Records Project. This does not rule out Philips's service, as there were 
Consistent with this picture were reports that Philips associated with escaped slaves: Will, who was "distinguished for [his] ferocity," "negro Sandy," Bob, and probably others. ${ }^{73}$ Recruiting slaves was an important part of Lord Dunmore's strategy in Norfolk in the fall of 1775. It culminated in his Proclamation of November 15, 1775, in which the governor declared all those "indented servants, Negroes, or others ... free, that are able and willing to bear arms" in the King's service. ${ }^{74}$ Between 800 and 1500 slaves fled to Dunmore. Some served as soldiers in a unit that Dunmore called the "Ethiopian Regiment," but others worked as spies or ship pilots. ${ }^{75}$ Philips may have recruited some of the men who fled, or they may have fled on their own and found him rather than Dunmore. In some communities, slaves expressed a significant emotional attachment to the king, whom they believed intended to emancipate them, and perhaps Philips delivered this message. ${ }^{76}$ Escaped slaves may have joined Philips to avoid being recaptured and sent to work in the lead mines in the far western part of the state, or even court martialed and executed. ${ }^{77}$ Legislative records show, as well, that jailed slaves occasionally escaped their confines and collected with other "outlyers" in swamps or highlands. ${ }^{78}$ Later in his

a number of British agents circulating in Virginia recruiting men and expressing disaffection with patriot leadership. Randolph asserts that Philips had a commission to recruit. Edmund Randolph, History of Virginia, ed. Arthur F. Schaffer (Charlottesville, VA: University of Virginia Press, 1970), 269.

73. Eckenrode, Revolution in Virginia, 192-93 (“ferocity," Bob); and Virginia Antiquary, 1:96-97 (Will and others).

74. Virginia Gazette (Dixon and Hunter), November 25, 1775, 3. As Sylvia Frey put it, the British desired "to inspire enough black resistance to satisfy British military needs without inciting rebellion.... Instead of calling slaves to arms, the British army summoned them to serve." Sylvia Frey, "Between Slavery and Freedom: Virginia Blacks in the American Revolution," Journal of Southern History 49 (1983): 389.

75. McDonnell, Politics of War, 140 n. 8; and Woody Holton, Black Americans in the Revolutionary Era: A Brief History with Documents (Boston: Bedford/St. Martin's, 2009), $8-9$.

76. Brendan McConville, The King's Three Faces: The Rise and Fall of Royal America, 1688-1776 (Chapel Hill: University of North Carolina Press, 2006), 170-81; and Holton, Black Americans, 8.

77. Petition of William Evans to the Speaker and Members of Both Houses of the General Assembly, October 27, 1790, Legislative Petitions of the General Assembly, 1776-1865, Accession Number 36121, Box 89, Folder 17, Library of Virginia; and Petition of Edmund Ruffin to the Speaker and Gentlemen of the House of Delegates, November 10, 1777, Legislative Petitions of the General Assembly, 1776-1865, Accession Number 36121, Box 23, Folder 5, Library of Virginia.

78. Petition of Robert Wilson to the Speaker and Members of the General Assembly, October 22, 1791, Legislative Petitions of the General Assembly, 1776-1865, Accession Number 36121, Box 150, Folder 24, Library of Virginia; and Petition of Arthur Dickenson to the Speaker and Gentlemen of the House of Delegates, May 27, 1778, 
career, Philips would hide away in the Great Dismal Swamp on the southern borders of Norfolk and Princess Anne Counties. ${ }^{79}$ At the time, thousands of men and women lived there, including maroons, runaway indentured white servants, Tuscarora Indians long separated from their tribe, and "the Scratch Hall folk, tawny skinned and neither white nor black." It is possible that Philips recruited "swampers" from these communities as well. ${ }^{80}$

Whether or not Philips recruited escaped slaves to his gang, from plantations or the swamps, he surely knew the effect their presence had on the imaginations of gentlemen planters. Maybe Will, Sandy and Bob did as well. The planter class suffered from a "permanent undercurrent of fear," in which every event seemed ominously to portend a bloody rising of the colony's 180,000 slaves. Three years before Philips got his start, in 1772, Chief Justice Mansfield of the King's Bench had concluded in Somerset v. Stewart that slavery had no basis in natural law or common law, implying that it depended on the local law of Virginia. The decision "caused a sensation in the colonies," and Virginia planters in particular "anticipated a ripening into bloody rebellion." 81 When Lord Dunmore seized gunpowder from the colonial magazine at Williamsburg in late April 1775, recalled Edmund Randolph, "it was believed ... that he designed, by disarming the people, to weaken the means of opposing an insurrection of the slaves," a policy Randolph described as "assassination." ${ }^{82}$ A day later, Dunmore remarked to a local physician working in the governor's palace that if his senior officers were injured in the tumult over the seizure, he would "declare freedom to the slaves \& reduce the City of Wmsburg to ashes." 83 The comment was rash, but the threat was clearly on his mind as he groped about for a way to seize the initiative.

Legislative Petitions of the General Assembly, 1776-1865, Accession Number 36121, Box 260, Folder 12, Library of Virginia.

79. Ulrich Troubetzkoy, “The Great Dismal Swamp," Virginia Calvacade 10 (1961): 19.

80. Ward, Between the Lines, 171.

81. Holton, Forced Founders, 138 ("permanent undercurrent of fear"); Hume, Another Part of the Field, 283-84; and Taylor, Internal Enemy, 21-22 (Somerset).

82. Randolph, History of Virginia, 219. In a statement to the House of Burgesses, John Randolph conceded that although he never "heard the Governor expressly say, that he would proclaim freedom to the Slaves, but he was so well satisfied that such was his Lordships Intentions," if he thought it necessary "in defence of his Person." Deposition of John Randolph in Regard to the Removal of the Powder, in "Virginia Legislative Papers (Continued)," Virginia Magazine of History and Biography 15 (1907): 149. On the connection between the gunpowder seizure and the fear of a slave uprising, see Hume, Another Part of the Field, 141-42.

83. Deposition of Dr. William Pasteur, in "Virginia Legislative Papers," Virginia Magazine of History and Biography 13 (1905): 49. 
Virginia gentry were scared; the week of the seizure saw "more rumors of slave plots ... than during any previous week in Virginia history"- $\mathrm{a}$ remarkable fact in a society habituated to rumor-mongering. ${ }^{84}$ Dunmore understood that Virginians' fear of insurrection was more than an abstract concern for property. Wealthy planters in particular "felt threatened by black Virginians in a personal, intimate manner." 85 The day after the British Victory at Kemp's Landing, in mid-October 1775, one woman recalled "an ugly looking negro man, dressed up in a full suit of British regimentals, and armed with a gun, came in upon us," asking for Virginia militiamen in "a saucy tone." Memory had knit together her revulsion at the man's appearance, his violent invasion of the home, and the British army. ${ }^{86}$

So how did Virginia's gentleman patriarchs see Josiah Philips? They saw him at the head of an "Ignorant disorderly mob" of poor, landless men. These were simple men. They lacked the independence and liberality characteristic of gentlemen. The laboring poor were in constant need, readily manipulated, and lacking in virtue and self-control, defects of character all plainly exhibited by their mobbing against convention policies. ${ }^{87}$ Gentlemen saw Philips with escaped slaves, too, or at least they heard the tales. This they would have found deeply threatening. Escaped slaves might foment insurrection among those still on their plantations. Slaves, and especially black men, posed a constant threat of domestic invasion and a sanguine, intimate violence described as "lust." 88 The violent slave

84. Holton, Black Americans, 7. For a sample of the unending stream of "fake news" in the Virginia press during this period, see Parkinson, The Common Cause, 213-39; and Hume, Another Part of the Field, 282-302, 335-42.

85. McDonnell, Politics of War, 143.

86. "My Mother," in Lower Norfolk County Antiquary, vol. 2, ed. Edward W. James (Baltimore: 1897), 134-35.

87. On the character of the Virginia gentleman, see Kevin Berland, Jan Kirsten Gilliam, and Kenneth A. Lockridge, eds., The Commonplace Book of William Byrd II of Westover (Chapel Hill: University of North Carolina Press, 2001), 82; and Isaac, Transformation of Virginia, 39, 131-33. On gentry views of white servants, sailors, convicts, "vagrants," and other groups of "deviant" whites, see Morgan, Hegemony of the Law, 140-48. According to Schwarz, "It always made a difference to communities whether [a] killer was of a lower status than the killed." Schwarz, Twice Condemned, 141.

88. Jefferson's famous account of black Virginians in Query XIV of Notes on the State of Virginia, suffused with a kind of scientific racism, described them as exhibiting a "lack of forethought" and black men as being "more ardent after their female," their "love [being equivalent to] an eager desire." Jefferson, Notes on the State of Virginia, 139. For a recent, highly compelling construction of Jefferson's view of black and poor "corporality," see Maurizio Valsania, Jefferson's Body: A Corporeal Biography (Charlottesville, VA: University of Virginia Press, 2017), 22-23, 109-12, 146-63. The sexualization of black violence was widespread. Consider the Petition of the Citizens of Halifax County opposing 
became, in Robert Parkinson's formulation, a "proxy" for the common enemy, a status that justified the use of exemplary violence. ${ }^{89}$ Even poor whites should understand the danger, planters thought. As Archibald Cary groused in a letter to another leading Virginian, "Men of all ranks resent the pointing a dagger to their Throats, thru the hands of their Slaves." 90

\section{Disorder and Attainder}

Move forward now several months. Philips disappears from the record for the moment, but likely he was busy stirring the pot, perhaps for Lord Dunmore. For the people of Norfolk and Princess Anne, patriot or loyal, the first months of 1776 were hard ones. On January 1, the borough of Norfolk was burned, largely by Virginia regulars. ${ }^{91}$ A week later, "sundry Inhabitants of Princess Anne and Norfolk Counties" composed a petition for the Fourth Provincial Convention in Williamsburg. Among the signers was Thomas Newton Sr., a Norfolk physician and merchant, and John Wilson, a former Burgess who would later serve as Norfolk County Lieutenant (head of the militia), as well as other leading gentlemen. Both men were from the area's long-established, leading families. ${ }^{92}$ They reminded the convention that they had supported its revolutionary measures, only to suffer under British occupation after the battle of Kemp's Landing. The presence of British soldiers had forced the men to "abandon...our aged Parents, our Wives, our Children, \& Families ... to

emancipation, which warned of "all the Rapes, Murders, and Outrages, which a vast multitude of unprincipled, unpropertied, vindictive, and remorseless Banditti are capable of perpetrating." Petition to the Virginia General Assembly, November 10, 1785, in Holton, Black Americans, 90-91. Even the abolitionist Benjamin Franklin could speak this way, describing "the wanton and unbridled Rage, Rapine and Lust, of Negroes, Mulattoes, and others, the vilest and most abandoned of Mankind." "Plain Truth," quoted in Gould, Among the Powers, 33.

89. Parkinson, Common Cause, 186-87, 227-29, 256-59; Lee, Crowds and Soldiers, 140-44; and Holton, Black Americans, 6-7. Holton observes that, although patriots accused Britain of fomenting slave rebellion, "[a] careful review of the chronology of the relationship ... shows that it was often the slaves who incited the British."

90. Cary to Richard Henry Lee (December 24, 1775), quoted in Holton, Black Americans, 10. As historian William Nelson describes this attitude, "the potential for black resistance arguably threatened poor whites as well as wealthy ones and thereby gave upper-class whites an argument for uniting the white underclass with them in their practices of repressing blacks." Nelson, Common Law, 3:32.

91. McDonnell, Politics of War, 135-74; and Eckenrode, Revolution in Virginia, 86-88. 92. Shepard, "The Administration of Justice," 85. 
the Mercy of insidious Neighbours, the lawless plundering Soldier, \& and the more savage Slave." The language of the plea spoke directly to the gentlemen who filled the convention. The anxiety, frustration, and shame of exposing one's dependents to abuse by "lawless" soldiers and "savage" black intruders would have been palpable; it was a basic failure of patriarchal duty. ${ }^{93}$ Indeed, the petitioners continued, "Our Plantations have been ravaged, our Wives \& Children stripped almost to Nakedness, our very Bed-Chambers invaded, at the silent Hour of Midnight, by Ruffians with drawn Daggers and \& Bayonets; our Houses not only robbed ... but wantonly reduced by Fire to Ashes; our Persons treated with every Indignity that elated Insolence \& Cruelty could suggest."

For the moment, British withdrawal had brought "a State of Safety," but it was temporary, and surely chaos would return with the redcoats. Before that happened, the petitioners insisted, those "suspected" of disaffection should be interrogated, and men who aided or fought with the British removed "to some distant part of the Colony." And although the convention had offered to pardon slaves who left Lord Dunmore's service, the petitioners did not "feel ourselves safe even at present, while they are suffered to go at large," and requested instead that slaves be "confined until an Opportunity offers to transport them to some of the West India Islands."94

The petition presented a dire picture, but provincial leadership was still hoping for rapprochement and no action was taken. Several months later, Major General Charles Lee of the continental army took up the cause again and framed it as a military imperative. Writing to the Committee of Safety, the state's wartime executive, Lee wrote that his field officers thought it "difficult, if not impossible, to secure and preserve the Province" if the many "dangerously dispos'd" remained in Norfolk.

93. This obligation lay near the center of the gentry worldview. Isaac, Transformation in Virginia, 131-32. For a period expression, see the letter from William Byrd II to Charles, Earl of Orrey, July 5, 1726, in "Virginia Council Journals," Virginia Magazine of History and Biography 32 (1924): 27. Jefferson, too, imagining himself as the "most blessed of the patriarchs" in a letter to a friend, placed himself at Monticello, surrounded by family (and books). It was an image he would invoke repeatedly. Rhys Isaac, "The First Monticello," in Jeffersonian Legacies, ed. Peter S. Onuf (Charlottesville, VA: University of Virginia Press, 1993), 90-91; and Annette Gordon-Reed and Peter S. Onuf, Most Blessed of the Patriarchs: Thomas Jefferson and the Empire of the Imagination (New York: Liveright Publishing, 2016), 28-40.

94. Petition of the Inhabitants of Norfolk and Princess Anne Counties, undated, in Revolutionary Virginia, The Road to Independence, vol. 5, The Class of Arms and the Fourth Convention, 1775-1776, ed. Robert L. Scribner and Brent Tarter (Charlottesville, VA: University of Virginia Press, 1979), 362-63. For a vivid account of a "midnight intrusion" into a bed chamber "with drawn daggers and bayonets," related by a family member of one of the Norfolk petitioners, see "My Mother," 136-37. 
They endangered not just the "preservation \& being of the Province, [but that] of the whole Continent." Such men should be removed inland, and to guarantee their good behavior the committee should take "their Wives and Children ... as hostages." ${ }^{95}$ Lee therefore joined Dunmore in exploiting for military advantage the domestic instability of the revolutionary household. ${ }^{96}$ The request was excessive, as was typical for Lee, but the situation worried the committee nonetheless. It had learned from another source of "a constant Intercourse" between the British fleet and disaffected Americans near the coast, and feared the provisions and intelligence flowing to the British would leave patriotic residents continually "exposed to the Depredations of the Enemy." In light of Lee's warning, the committee now ordered all individuals residing within the front lines "be immediately removed" into the interior and their slaves confined "at some secure place." "97 When locals objected, the order was relaxed to allow "friends or neutrals" "to remain at their habitations." 98 For his part, Lee thought the compromise inadequate, and "threatened to demolish the houses of several well-known loyalists in Portsmouth" as an example to the rest. 99

All the while, traditional government in Princess Anne and Norfolk largely ceased to function. The Norfolk County Court had heard no civil

95. Charles Lee to John Page, April 8, 1776, in Revolutionary Virginia, The Road to Independence, vol. 6, The Time for Decision, 1776, ed. Robert L. Scribner (Charlottesville, VA: University of Virginia Press, 1981), 352.

96. Carol Berkin, Revolutionary Mothers: Women in the Struggle for American Independence (New York: Knopf, 2005), 38-42.

97. Scriber and Tarter, Revolutionary Virginia, 5:402 n. 3; and Unanimous Resolution for the Evacuation of Parts of Norfolk and Princess Anne Counties, April 10, 1776, in Scribner, Revolutionary Virginia, 6:369-70.

98. Petition of the Committee of Safety of Princess Anne County, 1776, in "Virginia Legislative Papers (Continued)," Virginia Magazine of History and Biography 17 (1909): 173. The Princess Anne Committee asserted that only "fifteen or Twenty" of their slaves had joined Dunmore, and that, in general, "[w]e have but few" slaves. For the modified order, see Virginia Committee of Safety, Proceedings of the Committee, May 3, 1776, in Scribner, Revolutionary Virginia, 6:514.

99. Eckenrode, Revolution in Virginia, 91. A blanket removal was again ordered in October 1777. For the context of this order, which was made by Governor Patrick Henry and the Privy Council, see George, "Virginia Loyalists," 205; and Robert Leroy Hilldrup, "The Virginia Constitution of 1776: A Study in Revolutionary Politics" (PhD diss., University of Virginia, 1935), 119. The General Assembly indemnified the governor and the council for the removal: An Act for indemnifying the Governor and Council, and others, for removing and confining Suspected Persons during the late public danger. Hening, Statutes at Large, 9:373-74. Jefferson apparently drafted the statute, which appears in his papers. Bill Indemnifying the Executive for Removing and Confining Suspected Persons, in The Papers of Thomas Jefferson, vol. 2, 2 January 1777 to 18 June 1779, ed. Julian P. Boyd (Princeton, NJ: Princeton University Press, 1950), 119. 
suits since July 1774, though it continued to handle some administrative and criminal matters. Its courthouse was destroyed when the city burned, and court convened only three times between October 1775 and July 1777. After July it resumed its monthly meetings in a private home. ${ }^{100}$ The Norfolk Borough Hustings Court, whose jurisdiction was similar to that of the county court, did not hold a recorded meeting for 3 years after February 1775. In Princess Anne, the gentlemen justices met only twice between August 1775 and July 1776. Even when the justices met, however, the court could do little to enforce warrants and orders against the disaffected, because execution of its process depended, ultimately, on the militia, which was "inoperative." 101 At bottom, both the county court system and the local committees of safety relied on the cooperation of residents, and the people of Princess Anne and Norfolk were divided and fearful. Richard Beeman has argued that the ability of a county government "to serve the particular legal needs of nearly all the citizenry at the local level" was crucial in dampening disaffection in Virginia's southwest. The counties of the southeast were, in contrast, largely ungoverned during this period, and so it was that in the spring of 1776 "[1] oyalist banditti freely raided" in both Norfolk and Princess Anne. The raids abated when Dunmore left the area in late May, but increased again in 1777 and continued through much of the war. ${ }^{102}$

100. Other county courts were also affected by the outbreak of hostilities. The first Provincial Convention had permitted the court "fee bill" to expire, effectively closing the courts to suits for recovery of a debt, but justices in most counties remained active throughout the war collecting taxes, settling estates, convening grand juries, and generally preserving what one contemporary called "Peace and good Order." Lingley, Transition in Virginia, 70, 114 (fee bill); Shepard, "The Administration of Justice," 48-51; Alan McKinley Smith, "Virginia Lawyers, 1680-1776: The Birth of a Profession" (PhD diss., Johns Hopkins University, 1967), 39-40; Charles T. Cullen, St. George Tucker and Law in Virginia, 1772-1804 (New York: Garland Publishing, 1987), 31; and Robert L. Scribner, ed., Revolutionary Virginia, The Road to Independence, vol. 1, Forming Thunderclouds and the First Convention, 1763-1774 (Charlottesville, VA: University of Virginia Press), 280 ("Peace and good Order"). In July 1776, after enacting the state's new constitution, the Provincial Convention authorized county courts to resume sitting. Hening, Statutes at Large, 9:126. Norfolk courts would not sit regularly for at least another year.

101. Shepard, "The Administration of Justice," 52-53; Hast, Loyalism in Revolutionary Virginia, 92, 99; and An act to empower the justices of the county of Norfolk to hold Court at such place as they shall appoint, in Hening, Statutes at Large, 9:231.

102. Richard R. Beeman, "The Political Response to Social Conflict in the Southern Backcountry: A Comparative View of Virginia and the Carolinas during the Revolution," in An Uncivil War: The Southern Backcountry During the American Revolution, ed. Ronald Hoffman, Thad W. Tate, and Peter J. Albert (Charlottesville, VA: University of Virginia Press, 1985), 228, 233; and Ward, Between the Lines, 154 ("freely raided"). 
It is in this context that Josiah Philips reappears in the record, now graduated to leading a "conspiracy" rather than a mob. In June 1777 there is an entry in the Journal of the Virginia Council of State, describing a letter from Norfolk County Lieutenant John Wilson-whose petition to the convention we examined above - complaining of "sundry evil disposed persons, to the number of ten, or twelve," who "have conspired together, to foment a Dangerous Insurrection in the said County, and at present are lurking in secret places threatening and doing actual mischief to the peaceable and well affected Inhabitants." The party was led by "Levy Sikes, Josiah Phillips, and John Ashley." That theirs was a conspiracy to foment insurrection suggests a political motivation. Still, the conspiracy was likely not yet a great danger to the state, because Wilson requested a relatively small reward, $\$ 150$, for capturing the principals, whom, he said, were "to be dealt with according to Law," that is, by ordinary process of referral to the General Court for jury trial. This was enough; apparently Philips was captured. The following January, the council approved payment of an award to "sundry persons for apprehending Josiah Philips," with $£ 10$ to "a free Mulatto for inform ${ }^{\mathrm{g}}$ where the said Philips was."

Philips soon escaped. We don't know how, but escapes by loyalist prisoners were not uncommon when they had assistance. Several months later, on May 1, 1778, Governor Patrick Henry received a letter from County Lieutenant George Muter "informing him that Phillips the noted Traitor has again made an Insurrection in Princess Anne County at the head of fifty Men," and requesting 150 of the Nansemond militia to march against them. Muter requested, as well, that a significant reward of $\$ 500$ be offered for Philips's apprehension, "dead or alive," and that anyone participating be permitted a share in "the Booty taken from the said Insurgents."104 At approximately the same time, hearing "of ravages committed by Philips and his notorious gang," Lieutenant John Wilson called up men from four companies of the Norfolk militia, whose full force was "upward of two hundred." Ten men answered. Wilson "compelled twenty others

103. H. R. McIlwaine, ed., Journals of the Council of the State of Virginia, vol. 1, July 12, 1776-October 2, 1777 (Richmond: Virginia State Library, 1931), 435-36; and H. R. McIlwaine, ed., Journals of the Council of the State of Virginia, vol. 2, October 6, 1777-November 30, 1781 (Richmond: Virginia State Library, 1932), 58. The Journal states that Philips had been "outlawed by the Governor ... as a Traitor to the State," rather than simply bountied, but this is probably incorrect. Outlawry was a procedure at common law and in a strict sense beyond the power of the governor to perform. Elsewhere, as will be discussed, Henry expressly acknowledged the limits of his powers as governor to address the Philips threat.

104. H. R. McIlwaine, ed., Official Letters of the Governors of the State of Virginia, vol. 1, The Letters of Patrick Henry (Richmond: Virginia State Library, 1926), 267-68; and Mcllwaine, Journals of the Council, 2:127. 
into duty," placing them under the command of Captain Josiah Wilson, but a quarter of the force deserted the first night. Someone likely informed Philips of the mission, and the insurgents "were either taken to their secret places in the swamp, or concealed by their friends," so that "no intelligence could be obtained." The next day, Captain Wilson went to the house of a neighbor on some business. As he approached, he "was fired on by four men concealed in the house" and mortally wounded. Lieutenant Wilson wrote to the governor. Just as he had done 2 years earlier in the petition to the provincial convention, he now asked for a mass removal. Unless "the relations and friends of those villains" were removed from Norfolk, Wilson insisted, there could be no "peace and security."105

Within several months, the Philips gang would be broken up. Governor Henry agreed to offer a substantial award for Philips's capture and to order additional militia into the area-steps similar to those Congress had taken in response to the murder of a militia captain in Bladen County, North Carolina, the year before. ${ }^{106}$ Yet Henry thought "the executive power ... not competent" to satisfy Wilson's principal request, the mass removal of families "in league with the insurgents." According to Henry, the assembly were "the only judges [of] how far the methods of proceeding directed by law are to be dispensed with on this occasion." 107 Henry forwarded Wilson's letter to the House of Delegates on May 27, approximately a week after Wilson wrote, and the House took up the matter the next day. After deliberating for "some time" on a number of issues, the House concluded that Josiah Philips had "levied war" against Virginia, "committing murders, burning houses, wasting farms, and doing other acts of enormity." What evidence the delegates had before them, in addition to the letter, we do not know; Philips's conduct may have been widely known or merely rumored. The House resolved that Philips be attainted of treason and referred the matter to a select committee for drafting.

105. John Wilson to Patrick Henry, May 20, 1778, in William Wirt, The Life of Patrick Henry (Philadelphia: 1836), 237-38.

106. Lee, Crowds and Soldiers, 157-58. Congress examined witnesses to a reprisal killing and offered a reward for the capture of those believed responsible for the attack. In addition, its proclamation authorized pursuers to "kill and destroy" the suspects if they resisted.

107. Henry to Benjamin Harrison, May 27, 1778, in McIlwaine, Official Letters of the Governors, 1:282-83. The council had recommended that Henry remove the "[f]amilies as are in League with the Insurgents," and that for this purpose he should forward Wilson's letter to the assembly; in addition, the council recommended that Henry order a company of regulars to the area to cooperate with militia "in Crushing these Desperadoes." Mcllwaine, Journals of the Council, 2:140. 
This committee was led by Jefferson and included John Tyler Sr., a countycourt lawyer, future Anti-Federalist, and General Court judge. ${ }^{108}$

Perhaps Jefferson had already drafted a bill; years later, he would recall Henry approaching him immediately upon receiving Wilson's letter. In a study of the early Virginia executive, Emory Evans observed that it was not uncommon for governors to consult with members of the House, although it was usually through the speaker. Here there was clearly a sense that time was of the essence. Jefferson's committee reported a bill later the same day. It added robbery to the committee's charges of treason and murder, and gave Philips and his unnamed "associates and confederates" an opportunity to surrender and claim a trial. If Philips failed to surrender by the deadline, he would "suffer the pains of death," the "sentence of attainder" to be executed upon his capture "by order of the General court ... as soon as may be conveniently." Associates might still claim a trial on the question of their affiliation with Philips, but the caveat made for tenuous insurance; after the grace period it would be lawful for "any person" to "pursue and slay" a gang member. No objections to the bill are recorded. It was signed into law on June 1, a week after the House had taken up the matter. Philips had until to June 30 to surrender. ${ }^{109}$

\section{The Place of Legislative Attainder in the Republican Legal Mind}

If the status of legislative attainder was uncertain at the time of the imperial crisis, why did Jefferson turn to it so quickly? Years later, Jefferson would recall that, upon learning of Captain Josiah Wilson's murder, both he and Henry had "thought the best proceeding would be by bill of attainder, unless he delivered himself up for trial within a given time." Why? ${ }^{110}$

108. Report of the Committee on the State of the Commonwealth, May 28, 1778, in Journal of the House of Delegates [May 1778], 22-23. The clerk of the House who docketed the bill was Edmund Randolph. Journal of the House of Delegates [May 1778], 30; John P. Kaminski and Gaspare J. Saladino, eds., The Documentary History of the Ratification of the Constitution, vol. 9, Virginia, No. 2 (Madison, WI: Wisconsin Historical Society Press, 1990), 1004 n. 5.

109. Jefferson to William Wirt, August 14, 1814, in The Papers of Thomas Jefferson, Retirement Series, vol. 7, 28 November 1813-30 September 1814, ed. J. Jefferson Looney (Princeton, NJ: Princeton University Press 2010), 548-49 (Henry shared Wilson's letter with Jefferson); Emory G. Evans, "Executive Leadership in Virginia, 1776-1781: Henry, Jefferson, and Nelson," in Sovereign States in an Age of Uncertainty, ed. Ronald Hoffman and Peter J. Albert (Charlottesville: University of Virginia Press, 1981), 192-93, 204; Journal of the House of Delegates [May 1778], 22, 24, 28, 29, 35; Bill to Attaint Josiah Philips, May 28, 1778, in Papers of Thomas Jefferson, 2:189-91; and Hening, Statutes at Large, 9:463-64.

110. Jefferson to William Wirt, August 14, 1814, in Papers of Thomas Jefferson, Retirement Series, 7:549. 
With Jefferson, at least, no explanation would be complete that failed to take stock of the writings he obsessively consumed, and with which he sought to craft an enlightened, republican persona. An examination of these sources shows that Jefferson was familiar with bills of attainder by the time he served in the House of Delegates. Indeed, Jefferson's study of "the laws and course of Parliament" began early in his legal career. A letter to John Page written in 1766, when Jefferson was only 23 years old, expresses annoyance at the informality of proceedings in the Maryland legislature, using the peevish language of an initiate. By then Jefferson had been clerking in George Wythe's law office for 4 years, which would have been plenty of time to develop these prejudices, as well as some real expertise. In 1769, Wythe became clerk of the House of Burgesses and made his own study of parliamentary law, which Jefferson may have consulted, but Jefferson wrote later that he had "at an early period of life, read a good deal on the subject, and commonplaced what I read." Sometime in the late 1760s, Jefferson began to assemble a "Parliamentary Pocket-Book," commonplacing major parliamentary texts. The Parliamentary Pocket-Book contained several entries on attainder, including Coke's remark in the Fourth Part of the Institutes that Parliament had attainted Thomas Cromwell "without [his] being called to answer," but that such a practice, although lawful, ought to be forgotten. ${ }^{111}$

Early Pocket-Book entries were drawn primarily from the Modus Tenendi Parliamentum, a fourteenth century text, and George Petyt's seventeeth century Lex Parliamentaria, but Jefferson also had access to other sources from which he would have constructed his view of "the occasion and proper office of the bill of attainder." 112 In addition to the Fourth Part of the Institutes and Lex Parliamentaria, Jefferson ordered William Petyt's Jus Parliamentarium in October 1769, in preparation for his service in the colonial House of Burgesses, although the text may have been lost in the Shadwell fire. ${ }^{13}$ Jefferson acquired another important volume in 1773 or

111. Jefferson to John Page, May 25, 1766, in The Papers of Thomas Jefferson, vol. 1, 1760-1776, ed. Julian P. Boyd (Princeton, NJ: Princeton University Press, 1950), 19-20; Jefferson to George Wythe, February 28, 1800, in Jefferson's Parliamentary Writings, ed. Wilbur Samuel Howell (Princeton: Princeton University Press, 1988), 3 ("commonplaced what I read"); Howell, Jefferson's Parliamentary Writings, 43 (date Pocket-Book was begun); and Parliamentary Pocket-Book, para. 41, in Howell, Jefferson's Parliamentary Writings, 58 (Cromwell).

112. Jefferson to Louis Girardin, March 12, 1815, in Papers of Thomas Jefferson, Retirement Series, 8:334.

113. Perkins, Buchanan, \& Brown to Jefferson, October 2, 1769, in Papers of Thomas Jefferson, 1:34. 
thereabouts, Of the Judicature in Parliaments (1681), a tract traditionally attributed (erroneously) to John Selden, the English lawyer, member of Parliament and antiquarian. Judicature in Parliaments describes a number of English legislative prosecutions and proffers some limits on its jurisdiction. ${ }^{114}$ Probably more important than any of these law books, however, were two histories: History of the Rebellion (1720), by Edward Hyde, earl of Clarendon, and John Rushworth's Historical Collections of Private Passages of State (1721), the first of which Jefferson had read by $1771 .{ }^{115}$ Both volumes contain parliamentary speeches made during the attainder of Thomas Wentworth, earl of Strafford, describing what were thought to be signal limits on the legal powers of Parliament. ${ }^{116}$ One historian has concluded that Jefferson tended to prefer such "historical and political accounts of law," as evidenced in his patterns of commonplacing, which engage the sources more deeply than Jefferson did "legal reporting." 117 The great library of the Virginia Council of State, assuming it was still intact in 1778, held all these volumes as well. Recent bibliographic scholarship reveals that Jefferson relied on this library to guide him as the imperial crisis unfolded; it was, Jefferson wrote, "with the help ... of Rushworth, whom we rummaged over for the revolutionary precedents \& forms," that he, Patrick Henry and others had drafted a resolution in response to the Coercive Acts. ${ }^{118}$ Jefferson's flight to histories, precedents, and forms bears out Trevor Colbourn's observation, made years ago, that Jefferson treated Whiggish history as a vital source of experience, from which one could draw an understanding of the logic of contemporary events. ${ }^{119}$

114. The Thomas Jefferson"s Libraries database identifies the book as belonging to the "Monticello Library," assembled between 1770 and 1815; http://www.librarything.com/ work/4069900/book/22053709 (last accessed February, 22, 2019). Sowerby writes that "[J]efferson acquired this volume though his wife's family; the autograph signature of John Wayles occurs in three places ...." E. Millicent Sowerby, Catalogue of the Library of Thomas Jefferson, vol. 3 (Washington, DC: Library of Congress, 1953), 180, entry 2887. On the attribution of $O f$ the Judicature of Parliaments, see Elizabeth Read Foster, "The Painful Labour of Mr. Elsyng," Transactions of the American Philosophical Society 62 (1972): 5, 42-45.

115. Jefferson to Robert Skipwith, August 3, 1771, in Papers of Thomas Jefferson, 1:80.

116. On the importance of Rushworth to Jefferson's thinking, see Trevor Colbourn, The Lamp of Experience: Whig History and the Intellectual Origins of the American Revolution (Chapel Hill: University of North Carolina Press, 1965), 159-60.

117. Crow, Thomas Jefferson, Legal History, and the Art of Recollection, 73.

118. Paul Leicester Ford, ed., The Writings of Thomas Jefferson, vol. 1, 1760-1775 (New York: Putnam, 1892), 10; and Brent Tarter, "The Library of the Council of Colonial Virginia," in Billings and Tarter, "Esteemed Bookes of Lawe", 45-53.

119. Colbourn, Lamp of Experience, 160. 
In constructing Jefferson's views of attainder, one should also consider the account given in John Hatsell's influential tract, Precedents of Proceedings in the House of Commons, although Jefferson did not acquire the text until 1785. Jefferson repeatedly praised Hatsell and professed to rely heavily on it in preparing a manual of procedure for the United States Senate. ${ }^{120}$ The treatise contained many entries on attainder, listing individuals who had been attainted by Parliament and on what grounds. These proceedings had been aimed at "persons concerned in raising traitorous and tumultuous insurrections," particularly where it was impossible for "justice [to be] obtained by a regular trial in a court of criminal jurisdiction." Although bills of attainder had also been used to oppress, Hatsell disagreed with Blackstone that "proceeding by Bill is in no case expedient or proper," because it was not preferable that "the highest and most daring criminals against the State should escape with impunity, ... rather than that their crimes should be brought to the consideration of Parliament." Attainder in Parliament was justified "in cases of absolute necessity, ... where, from the magnitude of the crime, or the imminent danger to the state, it would be a greater public mischief to suffer the offense to go unpunished, than even to overstep the common boundaries of the law." Writing in 1815, Jefferson described the "proper office" of bills of attainder in precisely these terms, although his personal copy of Hatsell was by then packed in a book box for shipment to Congress, to which it had just been sold. ${ }^{121}$

Jefferson was uniquely well read, but there is evidence that Patrick Henry also viewed legislative attainder in this light. Henry is not known for his erudition, and famously claimed to have prepared for his bar examination by reading the First Part of the Institutes and the Laws of Virginia over the course of a single month. The picture is likely overdrawn. ${ }^{122}$ Wherever they came from, however, by 1776 Henry held strong views about the function of bills of attainder. According to Edmund Randolph's History of Virginia, it was Henry who succeeded in removing a prohibition of legislative attainder from a draft of the Virginia's first state

120. Howell, Jefferson's Parliamentary Writings, 43; and Lewis Deschler, Jefferson's Manual and the Rules of the House of Representatives (Washington, DC: United States Government Printing Office, 1961), 115 n. Jefferson wrote, "I could not doubt the necessity of quoting the sources of my information, among which Mr. Hatsel's most valuable book is preeminent."

121. John Hatsell, Precedents of Proceedings in the House of Commons, vol. 4 (London 1796), 89-90; Papers of Thomas Jefferson, Retirement Series, 8:334.

122. Kevin J. Hayes, "The Law Library of a Working Attorney: The Example of Patrick Henry," in Billings and Tarter, "Esteemed Bookes of Lawe", 140. This view of Henry is to some degree a product of William Wirt's early biography, whose emphasis on Henry's lack of book learning served to magnify Henry's legend in the minds of Virginia's advocates of local power, the "Old Republicans." Miller, Juries and Judges, 3-4. 
constitution, painting "a terrifying picture of some towering public offender against whom ordinary laws would be impotent" and thereby "saving that dread power from being expressly proscribed." Henry's attack was part of a larger effort by Virginia radicals to enhance the capacity of government to provide security by passing acts that functioned as judgments. Thus, against the draft's proposed ban of ex post facto laws, Thomas Ludwell Lee argued that retroactive lawmaking might be required by "the law of necessity - the exigencies of life," such as "when the safety of the State absolutely requires [it]." As one commentator described it, the radicals' aim was to give "martial law constitutional sanction," although the problem might also be described as setting proper boundaries between the common law and other, summary forms of legal proceeding, a task familiar to gentlemen raised in an empire of legal plurality. ${ }^{123}$ Much later, Henry would insist that this boundary could be demarcated using principles taken from natural law and the law of nations. Under these principles, Henry maintained, pirates and bandits lost their right to common law proceedings by having renounced government altogether. As the bandit, in effect, had waived his right to a jury trial, it was lawful to condemn him by the summary procedures used in the legislature for notorious offenses. Notably, Henry had long been interested in the law of nations and was well read in the publicist tradition. ${ }^{124}$

The influence of natural law and the law of nations on Henry's thinking was only strengthened by the transition to republican government. Bills of attainder fit naturally in a republican assembly. The gentlemen justices who presided over criminal trials in the county courts also sat in the assembly, comprising nearly half the members of the House of Delegates. ${ }^{125}$ Some of these men had English legal training, as has been mentioned. Nearly all of them took pains to distinguish their learning from that of the professional lawyers in Williamsburg. Gentlemen judged by what planter Landon Carter called "good reason and experience," not the "Mechanical" knowledge of professionals, whose learning, he gibed, amounted to "knowing from whom to Copy Properly." 126 When Virginia's great men, whom the evangelical minister Devereux Jarratt called "beings of a superior

123. Randolph, History of Virginia, 255 ("terrifying picture"); and Hilldrup, The Virginia Constitution, 183 ("martial law").

124. Kaminsky and Saladino, Documentary History of the Ratification, 9:1038; and Hayes, "The Law Library," 149-50.

125. Miller, Juries and Judges, 25. In contrast, professional lawyers made up 6\% of the membership of the House between 1720 and 1776. Roeber, Faithful Magistrates, 145.

126. Quoted in Isaac, Transformation, 133-34 ("good reason and experience"); and Jack P. Greene, ed., Diary of Landon Carter, vol. 1 (Richmond: Virginia Historical Society, 1965), 93 ("knowing from whom to Copy"). 
order," were gathered in assembly, they embodied "the corporate integrity of colony communities." 127 This was the place where the gentlemen fathers of the colonial family could decide together, as peers, how best to preserve the peace and safety of the colonial household. That such matters were appropriate for an assembly was precisely why the Virginia Constitution had not banned bills of attainder or ex post facto laws. Just as gentlemen justices did in the county courts, delegates in the House would decide on the proper form of law by drawing on their experience, reason, common sense, and basic principles of natural law and positive law. 128

Jefferson did not share the country justices' disdain for law books and precedents, of course, but his view of the legal powers of a republican assembly was similar to theirs. Normally, he thought, insurrections should be dealt with by exposing their agents "to the pains of the law." 129 In extraordinary circumstances, however, where courts of law could not operate effectively, Jefferson agreed that there was a residual power to do justice by some other means. Ancient precedents made this clear. If, strictly speaking, such a power had formerly been the prerogative of the king, under republican government it should be vested in the elected assembly, along with other royal prerogatives relating to security and justice. ${ }^{130}$ Acts of attainder were a natural, republican expression of the residual duty to do justice in extraordinary circumstances. ${ }^{131}$ To Jefferson's eye, the learning and refinement of his circle of friends in the House, under the guidance of professional lawyers sitting there, ensured that the body would proceed with moderation, prudence, and self-control, as these were the virtues that distinguished a natural aristocracy. ${ }^{132}$

127. Quoted in Roeber, Faithful Magistrates, 78 ("superior order"); Peter S. Onuf, "Thomas Jefferson, Federalist," in Mind of Thomas Jefferson, 90.

128. On the connection between family and state, see Peter S. Onuf, "Making Sense of Jefferson," 33.

129. Jefferson to William Preston, March 21, 1780, in Papers of Thomas Jefferson, 3:534-35.

130. Papers of Thomas Jefferson, 1:342. Jefferson's first draft of a constitution for the state of Virginia famously provides that the prerogative powers of declaring war or peace, issuing letters of marque and reprisal, and erecting courts are to "be exercised by the legislature alone."

131. Crow, Thomas Jefferson, Legal History, and the Art of Recollection, 88-89, 105. Notably, Jefferson's proposed revision of Virginia's colonial criminal laws, prepared close to the time of Philips's attainder, impliedly recognized a legislative power to attaint by bill, as it would prohibit only those attainders that worked a "corruption of blood"; that is, inherited civil disability. Bill for Proportioning Crimes and Punishments in Cases Heretofore Capital, in Papers of Thomas Jefferson, 2:506-7 n. 21.

132. Valsania, Jefferson's Body, 19-20, 27; and Roeber, Faithful Magistrates, 164. 
We should conclude, I think, that Jefferson and Henry were familiar with precedents for legislative attainder, and that these precedents were not diminished in their minds by Virginia's transition to republican government, but, in fact, had been enhanced. We should conclude, as well, that Jefferson and Henry believed precedent to support the use of attainder against Philips. Norfolk and Princess Anne were on the verge of lawlessness. Banditti including escaped slaves had invaded the homes of the gentlemen justices and their peers. They now struck directly at the military force directed by those same gentlemen. If delegates failed to address the murder of a militia captain from a great family such as the Wilsons, they would risk losing the cooperation of other men of ability and property, and the entire structure of the military and civil governance could collapse. Calling on these distant precedents, they hoped to direct the force of the community itself against the gang, reaffirming the leadership of great men and preserving the peace of their households against a deeply set fear of black violence. The audience for their argument was the men of the assembly, and in particular the House of Delegates, whose primacy in doing justice and maintaining security they recognized and supported. ${ }^{133}$

\section{The Breakup of the Gang}

As it turned out, however, an act of attainder was not necessary to preserve security in Norfolk and Princess Anne. The act passed against Philips almost certainly had no effect at all. What worked against Philips were the conventional institutions of civil government in wartime Virginia: the militias and the county courts. Extraordinary forms of law had been unnecessary.

The act of attainder was reported in Purdie's Virginia Gazette on June 5, 4 days after it passed. One day earlier, however, on June 4, Philips and an associate, James Hodges, were captured at night by a volunteer militia company led by Captain Amos Weeks. How this came about is unclear; another man affiliated with the gang, Henry M'Clelen, had been arrested several weeks earlier and may have provided intelligence. A week later, on June 11, 1778, Philips, Hodges, Cornelius Land (who had been sought since May), and Caleb Moore and Henry Burgess, two others likely associated with the gang, were all brought before the Princess Anne County

133. As Emory Evans describes, both Henry and Jefferson were "sensitive to and respectful of" the primacy of the legislature in the state government, even during wartime, and they consistently sought out authority from the legislature in the form of delegation, indemnification, or pardon. Evans, "Executive Leadership in Virginia," 191, 192, 202-3. 
Court for examination, where they faced a mass of county residents who had appeared to testify about their behavior. The charge was "feloniously robbing the Continent of America of sundry goods," including linen, bunting, buttons, hats and muskets - a haul suggestive of a continental army supply - and robbing another man of lead and powder. Witnesses were called, Philips and Hodges "heard in their defense," and the matter concluded, the county court binding the two men over to the General Court for charges of robbery, as was the usual practice for capital crimes. No mention was made of the bill of attainder. Its publication in the Gazette had occupied but one line, and the justices may not have known of it. ${ }^{134}$

The Norfolk County Court was busy as well. Two weeks later, on June 30, 1778, Wilson Pinkerton was charged in the death of Captain Josiah Wilson. Testimony was taken and Pinkerton was bound over for trial in a court of oyer and terminer to be held in Williamsburg. His testimony may have produced intelligence, or an effort to shift the blame, and further arrests were imminent. On July 16, Mason Miller and Robert Hodges appeared in court, Robert being a brother of James Hodges, who had been examined by the court in Princess Anne. Notably, Hodges and Miller's charge, "treason, murder and robbery," was now suggestive of the language of the act of attainder. The men were transferred to the General Court for trial. Later the same day, Thornton Miller was brought before the justices, charged with "High Treason, Murder, and Robbery," and bound over on all three charges. ${ }^{135}$

In the first days of August, two escaped slaves, "negro Sandy" and "Bob," were brought to the Norfolk County Court bar and also charged with treason and murder. Whose murder they are alleged to have committed the clerk's record does not say, but Sandy had belonged to Josiah Wilson, the murdered militia captain, and a charge of treason may have hinged on a belief that he had conspired in his master's death. ${ }^{136}$ As

134. Virginia Gazette (Purdie), June 5, 1778, 2 (act of attainder); Virginia Gazette (Purdie), June 19, 1778, 2 (Parker and Hodges jailed); Mcllwaine, Journals of the Council, 2:210 (Captain Amos Weeks); Princess Anne County Minute Book, May 16, 1778, microfilm, typescript, County Court Order Books, Library of Virginia (M'Clelen's arrest); Princess Anne County Minute Book, June 11, 1778 (arraignment of Philips, Hodges, Land, Moore, and Burgess); and Virginia Antiquary, 1:92-93 (Land).

135. Norfolk County Order Book, June 30, 1778 (Pinkerton); and Norfolk County Order Book, July 16, 1778 (Miller and Hodges).

136. During Jefferson's term as governor, Justices of the Peace Henry Lee and William Carr dissented from the judgment of the Prince William County Court condemning a slave Billy to death for high treason, on the grounds that he was not a citizen and therefore did not owe the state allegiance and could not commit treason. William P. Palmer, ed., Calendar of Virginia State Papers and Other Manuscripts [...], vol. 2, April 1, 1781 to December 31, 1781 (Richmond, 1881), 90-91. Billy's owner, Mann Page, appealed to 
recorded by the clerk, both Sandy and Bob testified that they were "in no wise guilty," but the language is formulaic and the substance of their defense is not revealed. Sitting as a court of oyer and terminer, the justices could try slaves without a jury, and both Sandy and Bob were convicted and sentenced to be executed at the end of the week. After sentencing Bob, the gentlemen justices added an order "that the Sheriff do hang up the Body of the said Bob, after it is Dead, at some Place near that of Execution, to wit where Sandy, belonging to Josiah Wilson, is to be hung up, that is where they shall be most conspicuous, and least offensive, and there leave it to remain." 137 The intent of the punishment, which one exhaustive study describes as "severe and unusual for Norfolk," was surely to use Sandy and Bob's decaying bodies to terrorize other slaves. The special criminal jurisdiction that the county court possessed over slaves - a jurisdiction it did not possess over the cases of free banditti-empowered the gentlemen justices to use the court to quiet their own fears about slave insurrection. ${ }^{138}$

The next day Jesse Phillpot was brought before the justices, charged with treason and murder, heard in his defense, and bound over for trial in Williamsburg. Phillpot was simultaneously being sued in a civil action on a writ of trespass in Princess Anne, in which the plaintiff described him as working with two black men, "Will ... and the other Negro," robbing multiple houses in the course of one night. This was the "ferocious' Will, later accused of "aiding and abetting Josiah Phillips," and who "struck such terror into the inhabitants of Norfolk and Princess Anne" that County Lieutenant John Wilson had personally offered a $£ 100$ reward to whomever "should put him to death." The reward went to Zadock Dailey, who had deserted his company of Virginia regulars but now earned a pardon and $£ 100$ for killing Will. Phillpot, for his part, was tried in Williamsburg in March 1779, along with Pinkerton, Miller, and

Jefferson, who granted a reprieve on that ground. Mann then petitioned the House for a pardon, and a bill of pardon was ordered prepared; whether it passed out of the House, and whether it ever went to the Senate (or was required to), is unknown. Journal of the House of Delegates of the Commonwealth of Virginia; Begun [...] Monday, the Seventh Day of May, in the Year of our Lord One Thousand Seven Hundred and Eighty-One (Richmond: 1828), 12 (entry for June 9, 1781); Eckenrode, Revolution in Virginia, 259. In this case, Sandy might have been charged with petit treason for the murder of his master, although the record contains no such language.

137. Norfolk County Order Book, August 3, 1778 and August 5, 1778.

138. Shepard, "The Norfolk Courts," 80 . As Shepard notes, there were a relatively large number of slaves tried before county courts of oyer and teriminer in 1778, suggesting the possibility of other escaped slaves in Philips's gang, although the records do not confirm this. 
Thornton, who were all found guilty and sentenced to death. ${ }^{139}$ Yet Phillpot, at least, was never executed. He died peacefully several years later in Princess Anne, wealthy enough to own two slaves. The result, although surprising, was not unheard of in counties like Princess Anne and Norfolk, where "local dynamics of loyalism" (combined with a limited capacity to imprison people) made it possible even for men charged with treason to return to the community. The Virginia Gazette never reported the execution of Pinkerton, Miller, and Thornton; perhaps they, too, were pardoned or escaped. ${ }^{140}$ We read of no redemption for Sandy or Bob. ${ }^{141}$

Put under heavy guard, Philips waited for 3 months in a Williamsburg jail to be tried on charges of felony robbery. In October 1778, he was indicted on charges of feloniously robbing some hats and twine. The magnificence of his crimes was now dwindling in the record. The Virginia Gazette reported that Philips had allegedly "robb[ed] the publick waggons," although it added, parenthetically, sensing that a reminder was needed, that the man had earlier been "accused of murder, treason, and sundry other outrages." The jury found him guilty. Philips, Robert Hodges, James Hodges, and Henry M'Clelen were sentenced to death and executed by hanging in December $1778 .{ }^{142}$

Disorder lived on for some time in Princess Anne and Norfolk. Nearly 2 years after Philips's execution, in September 1781, County Lieutenant Thomas Newton wrote Governor Nelson that Princess Anne "has neither civil nor military law in it," so that "Murder is committed \& no notice is taken of it." Some of Philips's associates had managed to evade capture

139. Virginia Antiquary, 1:96 (Phillpot and Will); Journal of the House of Delegates of the Commonwealth of Virginia; Begun [...] Monday, the Fifth Day of October, in the Year of our Lord One Thousand Seven Hundred and Seventy-Eight (Richmond, 1827), 39, 55 (entries for November 2, 1778 and November 11, 1778); Mcllwaine, Letters of the Governors, 1:308; and Virginia Gazette (Dixon and Nicholson), March 26, 1779, 2 (Phillpot, Pinkerton, Miller, and Thornton sentenced).

140. Virginia Antiquary, 1:119. The discovery of this remarkable fact should be credited to Adele Hast. Hast, Loyalism in Revolutionary Virginia, 98.

141. Slaves could not appeal a conviction for felony in a county court of oyer and terminer, and had to hope for a gubernatorial pardon. Shepard, "The Administration of Justice," 21.

142. Mcllwaine, Letters of the Governors, 1:300 (Philips's transfer to Williamsburg in July 1778); Virginia Gazette (Purdie), October 30, 1778, 3 (indictment); and "An endictment against Josiah Philips for robbery," October 20, 1778, Verdict, October 27, 1778, Judgment, October 28, 1778, Report of Sentence, October 30, 1778, all in Wirt, Life of Patrick Henry, 465-68. The records of the General Court were burned in the Civil War, but William Wirt had copied them for inclusion in his biography of Henry. Wirt noted that the indictment was "endorsed ... in Mr. Randolph's handwriting." For a contemporaneous report of the sentence and execution, see Virginia Gazette (Dixon and Hunter), October 30, 1778; and Virginia Gazette (Dixon and Hunter), December 4, 1778, 2. 
and continued to launch raids from the Great Dismal Swamp. Newton reported that "a few desperate fellows go about on the sea Coasts and large Swamps and do mischiefs in the nights." Over time, however, Newton was able to use the militia effectively against the bandits, who were captured and charged in the county courts. A letter to the governor 1 year later was more hopeful. There were "[m]any refugees out in the Swamps ... anxious to come in," he thought. A few of Philips's old comrades, "Levi Sikes \& Robt. Stewart," were unlikely to reform, but if the others were pardoned, "the whole nest would be broken up."143

\section{Consequents: Professionalization and the Fall of Legislative Law}

If the act attainting Philips of treason was experienced by the gentlemen of the General Assembly as an exercise of that body's extraordinary legal power, how did it come to stand, 10 years later, for a tyrannical violation of rights? What accounts for the difference between experience and memory?

Speaking to the convention considering a proposed federal Constitution in 1788, Virginia Governor Edmund Randolph recalled the Philips affair, describing how "a man had been deprived of his life" in a rushed proceeding, in which "vague reports" of his "committing several crimes" and "running at large" were brought to the House floor and a legislator had drawn "from his pocket a bill ready written" to attaint him. Philips was "sentenced to death," Randolph announced, "without being confronted with his accuser and witness; without the privilege of calling for evidence." Missing from Randolph's account was Philips the "laborer"; missing was the banditti of escaped slaves; murder and arson had become "several crimes"; and the legislature's deliberations had become a reliance on "vague reports." Omitted entirely was Philips's jury trial on charges of robbery. ${ }^{144}$ Where did this view of the case come from? ${ }^{145}$

143. Thomas Newton Jr., to Thomas Nelson Jr., September 17, 1781, in Palmer, Calendar of Virginia State Papers, 2:450-51 ("neither civil nor military law"); George, "Virginia Loyalists," 204; Shepard, "The Administration of Justice," 79; and Thomas Newton to Benjamin Harrison, August 9, 1782, in William P. Palmer, ed., Calendar of Virginia State Papers and Other Manuscripts, vol. 3, January 1, 1782 to December 31, 1784 (Richmond, 1883), 252 ("the whole nest").

144. Kaminsky and Saladino, Documentary History of the Ratification, 9:972.

145. The convention returned to the subject of Philips repeatedly. Patrick Henry took up the defense of Philips's attainder but did not contest the essentials of Randolph's account, other than to insist that Philips was "a fugitive murderer and an outlaw." Kaminsky and Saladino, Documentary History of the Ratification, 9:1038. Like Randolph, Henry failed to mention the slaves in Philips's gang, although slavery and the fear of slave insurrection 
Randolph was probably not being dishonest. As he knew, a number of men in the audience were familiar with the case, in one way or another, and might have advanced their cause by exposing his dishonesty. For Randolph to have taken such a risk would have been reckless. Jefferson himself, whose view of Randolph was typically lukewarm, did not think he had been lying. ${ }^{146}$ Nor was Randolph misinformed; he had been personally involved in bringing Philips to justice, both as clerk of the House of Delegates when the bill of attainder was passed, and, later, as state attorney general when Philips was prosecuted. Although it is possible that Randolph's memory failed (and, we must assume, that other delegates who knew of the case were unable or unwilling to correct him), it seems more likely that his perspective on the event had changed. Patrick Henry had set the agenda at the ratifying convention by arguing that the proposed federal Constitution would deprive Virginians of the liberty that they had enjoyed under their own constitution. Henry had no faith that the "rope-dancing, chain rattling, ridiculous ideal checks" Madison had implanted in the federal Constitution would constrain its government. In reality, an energetic, superior national government would overwhelm the states and then absorb them. ${ }^{147}$ Randolph's strategy was to insist, against Henry, that Virginians' liberty was already at risk. Virginians were insecure, he argued, even under the state's venerable Declaration of Rights, because "a man" had been "sentenced to death" by the General Assembly, acting merely on "vague reports" that he committed "several crimes" and was now "running at large." A federal Constitution would secure liberty in Virginia by prohibiting these proceedings. ${ }^{148}$

Of course, Randolph enhanced the rhetorical value of the case by failing to describe Philips or his gang of escaped slaves. But as we know, he was

featured centrally in arguments that Henry advanced against ratification. Robin L. Einhorn, "Patrick Henry's Case against the Constitution: The Problem with Slavery," Journal of the Early Republic 22 (2002): 549-55. John Marshall, George Nicholas, and Edmund Pendleton also addressed the Philips case, although none of them pressed Randolph on his description or added significant details. Kaminsky and Saladino, Documentary History of the Ratification, 9:1086, 1116, 1127, 1333; and John P. Kaminski and Gaspare J. Saladino, eds., The Documentary History of the Ratification of the Constitution, vol. 10, Virginia, No. 3 (Madison, WI: Wisconsin Historical Society Press, 1993), 1197.

146. Matthew Steilen, "The Josiah Philips Attainder and the Institutional Structure of the American Revolution," Howard Law Journal 60 (2017): 434-42.

147. Kaminsky and Saladino, Documentary History of the Ratification, 9:959; and Pauline Maier, Ratification: The People Debate the Constitution, 1787-1788 (New York: Simon and Schuster, 2015), 257-60. For a recent account of the convention that treats Randolph quite harshly, see Lori Glover, The Fate of the Revolution: Virginians Debate the Constitution (Baltimore: Johns Hopkins Press, 2016), 110-14.

148. Kaminsky and Saladino, Documentary History of the Ratification, 9:951-52. 
wise to omit these facts, because they almost surely would have obscured his key point: that the gang never really posed a serious danger to the state. If Philips was so dangerous, then why had he been caught by a voluntary militia company? What need had there been, really, for the legislature's extraordinary intervention? The same skepticism is apparent in Randolph's account of the case in his History of Virginia, written in 1810 or thereabouts. If Philips's crimes were so heinous and widely known - if they were, in short, legally "notorious"- then why was he convicted of robbing twine and some felt hats? And if petty robbery could be transformed on the House floor into a brigandage so great it that threatened civil government itself, what offense could not? The success of ordinary law and ordinary executive power gave the legal arguments on which Jefferson and Henry had relied a kind of sophistic quality. Pivoting between extraordinary and ordinary forms of law produced an impression of the legislature's arbitrary discretion, just as it did when local justices of the peace pivoted from law to equity in an effort to resolve a case before them. And where there was arbitrary discretion, passion and interest tended to corrupt the exercise of power. For delegates at the convention hearing this exchange, the concerns they knew from the long-running public debate over reform of the county courts must have seemed, in a flash, to apply to the General Assembly as well. ${ }^{149}$

A worry had been growing about the character of the men seated in the House of Delegates. As early as 1781 , Jefferson was prepared to admit that its members were neither a natural aristocracy nor under the influence of elite lawyers to the degree that he had expected they would be. Because no one could resist "proceedings [in] the form of an act of assembly," he conceded, the House had, "in many instances, decided rights which should have been left to judiciary controversy." Jefferson had been wrong, then, to think assembled bodies of leading men the safest repository of a power to settle boundaries between ordinary and extraordinary forms of law. His 1783 draft of a state constitution accordingly banned bills of attainder outright. Other Virginia elites saw the problem as well. Writing in 1786, Ralph Wormeley worried about "[t]he crude state of politics in this country." 150 A short time later, preparing for an opening address at the constitutional convention in Philadelphia, James Madison devoted the keenest of his complaints in "Vices of the Political System of the

149. Randolph, History of Virginia, 268-69; and Roeber, Faithful Magistrates, 104.

150. Jefferson, Notes on the State of Virginia, 120; Jefferson's Draft of a Constitution for Virginia, in The Papers of Thomas Jefferson, vol. 6, 21 May 1781 to 1 March 1784, ed. Julian P. Boyd (Princeton, NJ: Princeton University Press, 1952), 298; and Ralph Wormeley Letterbook (June 13, 1786), quoted in Roeber, Faithful Magistrates, 177. 
U.S." to the vicissitudes, injustice, and low character of the state assemblies. Madison had just finished serving in the Virginia House of Delegates, where he had been struggling to push through a reform of the state's court system. ${ }^{151}$

The movement to reform the county courts was tied up with clashing conceptions of the practice of law in Virginia, conceptions we have been tracing throughout this article. According to Alan McKinley Smith, "the single factor most essential to the development of a legal profession in Virginia was, of course, the court system." This was because institutional and cultural boundaries separated lawyers practicing in the state's different courts. In 1748, the General Assembly had barred attorneys practicing before the central General Court from also practicing in the county courts, acting on petition from one of the counties, but the principal effect was to "create a legal elite" in Williamsburg. There the state's "philosophical lawyers" embraced a movement toward liberal education that had distinguished elite English barristers. But others had little patience for these embellishments. Writing from Bermuda, St. George Tucker's father, Henry, could not understand why his son insisted on taking courses in natural philosophy, moral philosophy, and mathematics, "an Academical education" unnecessary for the practice of law (and expensive, given William \& Mary's tuition). ${ }^{152}$ Justices of the peace largely shared this attitude and resisted efforts by the elite to export its methods to their courts. In 1779, gentleman justices sitting in the House of Delegates had fought off a bill that would have required them to purchase law books with fees levied from litigants. The ideology of "country" opposition still had currency, and from this perspective the professionalization and centralization of the law was a source of corruption and a threat to liberty; liberty that Virginia gentlemen had long preserved by independently administering justice in the counties according to common sense, experience, and basic

151. "Vices of the Political System of the U.S." (April 1787), in The Founders' Constitution, vol. 1, ed. Philip B. Kurland and Ralph Lerner (Chicago: University of Chicago Press, 1987); and Mary Sarah Bilder, Madison's Hand: Revising the Constitutional Convention (Cambridge, MA: Harvard University Press, 2015), 35.

152. Henry Tucker to St. George Tucker, April 10, 1772, quoted in Smith, "Virginia Lawyers, 1680-1776," 39-40; Cullen, Tucker and Law in Virginia, 8-9; Smith, "Virginia Lawyers," 2, 302-3 ("create a legal elite," "philosophical lawyers"); David Lemmings, Professors of the Law: Barristers and English Legal Culture in the Eighteenth Century (Oxford: Oxford University Press, 2000), 17, 241-42; and Gerard W. Gawalt, The Promise of Power: The Emergence of a Legal Profession in Massachusetts, 1760-1840 (Westport, CT: Greenwood Press, 1979), 4, 18-19. Both Lemmings and Gawalt show that Americans working to professionalize the practice of law tended to adopt the English ideal of the "good lawyer," who was liberally educated, morally upright, and an "independent" gentleman. 
legal maxims. Eventually, reformers settled on a plan that had judges from the central courts riding circuit throughout the state, with the hope of improving the quality and speed of local justice and gradually displacing county proceedings. The leading proposals for reform in the 1780 s therefore called for assize courts or district courts staffed by General Court, admiralty and chancery judges, possessed of a jurisdiction that trenched deeply on the county court. (Tucker himself would soon ride circuit as a General Court judge.) ${ }^{153}$ The aim was to create "the machinery ... to assure a rational, systematic law." Were gentlemen justices who sat as members of the House of Delegates to enjoy a power to interfere with proceedings before these courts, however it would have precisely the opposite effect. ${ }^{154}$

With the argument for legislative jurisdiction over Philips stripped away, what remained of the case was simply interference in the judicial process. Henry and Jefferson were unbothered because they continued to credit the argument that justified the attainder: the Philips gang had threatened government itself. At least initially, Jefferson was comfortable with extraordinary legislative jurisdiction in cases in which it was necessary to protect the state, as the assembly would comprise the state's greatest men and act under the guidance of lawyers sitting there. But to others, less impressed by Philips and perhaps by the assembly as well, the interference was intolerable. St. George Tucker, a lawyer by training but a gentleman planter only by marriage, used his edition of Blackstone's Commentaries to fume about acts of attainder. They were, he wrote, "state-engines of oppression in the last resort," characterized by a "want of legal forms, legal evidence, and every other barrier which the laws provide against tyranny and injustice in ordinary cases." Ordinary cases, Tucker thought, adjudicated in courts of law, would be decided according to legal forms that gave forensics a greater precision. The movement to professionalize the practice of law drew strength from a number of sources, but a desire

153. Roeber, Faithful Magistrates, 113, 160-202; and Miller, Juries and Judges, 5-11, 24-26. On Tucker's tenure as a General Court judge, see Charles F. Hobson, "St. George Tucker: Judge, Legal Scholar, and Reformer of Virginia Law," in Billings and Tarter, "Esteemed Bookes of Lawe", 198-99, 212-13. Although he did ride circuit, Tucker had initially favored the creation of locally staffed intermediate courts, presumably because such a system would better preserve local control. George Wythe to St. George Tucker, October 10, 1784, Wolf Law Library, William \& Mary School of Law, http:/lawlibrary.wm.edu/wythepedia/index.php/Wythe_to_St._George_Tucker,_10_October_1784 (last accessed February 22, 2019).

154. Miller, Juries and Judges, 25 ("machinery"). On the effect district courts had on Virginia legal culture and the county courts, see Cullen, Tucker and Law in Virginia, 8384; and Charles F. Hobson, ed., St. George Tucker's Law Reports and Selected Papers, 1782-1825 (Chapel Hill: University of North Carolina Press, 2013), 36. 
to render law more scientific and thereby narrow judicial discretion was repeated and found an audience among lawyers and merchants in Williamsburg and Richmond. Blackstone's Commentaries, with its rational, "institutional" methodology and clear legal principles, was their preferred law book. ${ }^{155}$

To secure the benefits of professionalized law required a means of insulating courts from arbitrary interference by the assembly. A superior national government, whose Constitution forbade state bills of attainder and ex post facto laws, was one such mechanism. Another was a judicially enforceable boundary between the assembly and courts of law. Once legal proceedings in the assembly were stripped of their lawyerly defenses, they took on the appearance of an abuse of lawmaking power, of arbitrary or factional expressions of will. St. George Tucker again pointed the way. Josiah Philips, he wrote, had been saved by the brave refusal of judges of the General Court to execute the sentence of death mandated by the act of attainder. The court "refused to pass the sentence," insisting instead that Philips "be put upon his trial, according to the ordinary course of law." The episode was, he thought, "decisive proof of the separation of powers, and of the independency of the judiciary." At the time Tucker was writing, judicial independence was "in the air," as judges sitting on the state's constitutionally established courts sought to defend their jurisdiction from what they argued were unconstitutional legislative alterations. ${ }^{156}$

Tucker claimed that the General Court had invalidated the act of attainder by judicial review. Commentators have long expressed skepticism that the General Court did in fact refuse to comply, because Philips was captured before the end of the attainder's grace period and therefore could not have been, consistent with its terms, executed on its sentence. ${ }^{157}$ Yet we can still account for much of Tucker's view if we attenuate, slightly, his version of events; perhaps, in informal conversation with Attorney General Randolph, judges expressed skepticism that Philips's crimes could legally constitute treason, as the act of attainder alleged. ${ }^{158}$

155. Tucker, Blackstone's Commentaries, 292-93; Michael Lobban, The Common Law and English Jurisprudence, 1760-1850 (Cambridge: Cambridge University Press, 1991), 57-61; and Cullen, Tucker and Law in Virginia, 127-30.

156. Tucker, Blackstone's Commentaries, 293. The struggle between the General Assembly and the judges of the Court of Appeals had already resulted in the "Remonstrance of 1788," and would again be at issue in the case of Kamper v. Hawkins (1794). Cullen, Tucker and Law in Virginia, 80-94; and Hamburger, Law and Judicial Duty, 559-74.

157. Jesse Turner, “A Phantom Precedent," American Law Review 48 (1914): 322-23; W. P. Trent, "The Case of Josiah Philips," American Historical Review 1 (1896): 451.

158. Steilen, "Josiah Philips Attainder," 444-45. 
Whether or not Tucker was correct about the details, his framing of the case prepared law students to envision a new role for courts of law: policing the boundaries between "legislative" and "judicial" functions. In drawing that line, courts and lawyers would now decide when a matter was appropriately resolved by the ordinary course of law and when it was fit for determination in the legislative or executive branches. ${ }^{159}$ Judges would construct a doctrine that kept each branch in its proper sphere, preserving for themselves a class of decisions that required "due process." The old vision of plural regimes of law, including an extraordinary body of legislative law for doing justice in cases of civil conflict, was giving way to a judicial doctrine of separation of powers.

$* * *$

These changes did not occur solely in Virginia, although they occurred at different rates in different places, and were forced even to retreat in some states by the advance of Jeffersonian Republicans in the state legislature. ${ }^{160}$ But, generally speaking, the "cosmopolitan elites" who defended loyalists from charges of treason during the Revolution and who led efforts to reclaim their property afterwards, and who emerged as some of the most vigorous public advocates of the practice of judicial review, also placed bills of attainder and ex post facto laws at the center of their persuasive efforts. The federal Constitution's prohibition of bills of attainder was, wrote Alexander Hamilton as Publius, one of those "specific exceptions to legislative authority" that could "be preserved in practice no other way than through the medium of the courts." Bills of attainder, observed James Wilson in his Lectures on Law, were simply "legislative verdicts." They were arbitrary exercises of legislative power. No trace remained in either commentary of the legislature's authority to adjudicate notorious cases, despite the revolutionary practices of both Hamilton's New York and Wilson's Pennsylvania, whose governments together attainted hundreds of American loyalists and British subjects. ${ }^{161}$ By 1795, William

159. Gerald Leonard, "Jefferson's Constitutions," in Constitutions and the Classics: Patterns of Constitutional Thought from Fortescue to Bentham, ed. Denis Galligan (Oxford: Oxford University Press, 2014), 376-78; and David Thomas Konig, Nature's Advocate: Thomas Jefferson and the Republic of Law (forthcoming), ch. 4.

160. Gordon S. Wood, Empire of Liberty: A History of the Early Republic, 1789-1815 (Oxford: Oxford University Press, 2009), 425-32; and John Phillip Reid, Controlling the Law: Legal Politics in Early National New Hampshire (Dekalb, IL: Northern Illinois University Press, 2004).

161. Daniel J. Hulsebosch, "A Discrete and Cosmopolitan Minority: The Loyalists, The Atlantic World, and the Origins of Judicial Review," Chicago-Kent Law Review 81 (2006): 835-38; Benjamin Fletcher Wright, ed., No. 78, The Federalist (Cambridge, MA: 
Paterson of New Jersey (whose state had also confiscated the land of loyalists during the Revolution), now a justice of the United States Supreme Court, rejected the argument of counsel in Vanhorne's Lessee $v$. Dorrance that legislatures had a power "on certain emergencies" to seize the lands of one person and vest them in another. To Paterson's mind, this sort of thing had to be done in court. In court, "proofs and allegations" would be heard by a jury; but in the legislature, wrote Paterson, "[t]he proprietor stands afar off, a solitary and unprotected member of the community, and is stript off his property, without his consent, without a hearing, without notice, [and] without his participation, or the intervention of a jury." One can almost imagine Philips, "standing afar off," hiding somewhere in the Great Dismal Swamp, unaware that his life was at stake in the Virginia House of Delegates. ${ }^{162}$

If Philips appeared too early to benefit from an emerging practice of judicial review and separation of powers, there was no such temporal irony for Will, Sandy, and Bob. Slave fear, and the domestic law of slavery that justices applied to enslaved persons, would of course remain intact in Virginia for many years to come. ${ }^{163}$ And on this front there was little help from "cosmopolitans" such as St. George Tucker, who, while professing to detest slavery and employing judicial review to check the actions of Virginia planters sitting in the General Assembly, eventually sided with these same men on the subject of slavery, on the grounds, in the words of one historian, that "blacks were incapable of freedom and happiest under the benign rule of their paternalistic masters." 164 Enslaved men and women were excepted even from the benefits of Virginia's constitutional law. Writing in 1806, Judge Tucker of the Virginia Court of Appeals squinted at the soaring language of the state's Declaration of Rights that "freedom is the birth-right of every human being," remarking that it had been "notoriously framed with a cautious eye to this subject, and was meant to embrace the case of free citizens, or aliens only; and not by a side wind ... to give freedom to those very people whom we have been compelled from imperious circumstances to retain, generally,

Harvard University Press, 1961), 429; James Wilson, Lectures on Law, Part II, Lecture VI (1790), in The Works of James Wilson, vol. 2, ed. Robert Green McCloskey (Cambridge, MA: Harvard University Press, 1967), 548; and Steilen, "Bills of Attainder," 826-89 (attainder in revolutionary New York and Pennsylvania).

162. Vanhorne's Lessee v. Dorrance, 2 Dall. 304, 310, 316 (C.C.D.Pa. 1795); An Act for forfeiting to, and vesting in, the State of New Jersey, the Real Estates of certain Fugitives and Offenders [... ], in Acts of the Council and General Assembly of the State of New Jersey [... ], vol. 1, ed. Peter Wilson (Trenton, NJ: 1784), 67.

163. Schwarz, Twice Condemned, chap. 8.

164. Taylor, Internal Enemy, 107. 
in the same state of bondage that they were in at the revolution." For judgment of Tucker on this point we can quote his own words, written a decade earlier in his Dissertation on Slavery, concerning just such an about-face: "[T] hat a people who have declared, 'That all men are by nature equally free and independent,' and have made this declaration the first article in the foundation of their government, should in defiance of so sacred a truth, recognized by themselves in so solemn a manner, ... tolerate a practice incompatible therewith, is evidence of the weakness and inconsistency of human nature." 165

A cruel legal plurality lived on for the enslaved. ${ }^{166}$

165. Hudgins v. Wright, 1 Hen. \& M. 134, 141 (Va. 1806); St. George Tucker, Blackstone's Commentaries: With Notes of Reference [...], vol. 2 (Philadelphia: 1803), appendix H, 41-42.

166. Halliday, "Law's Histories," 271. 
Copyright (c) the American Society for Legal History,

Inc. 2019 